\title{
Origin of the moisture feeding the Heavy Precipitating Systems over Southeastern France
}

\author{
F. Duffourg and V. Ducrocq \\ Centre National de Recherches Météorologiques - Groupe d'étude de l'Atmosphère Météorologique, \\ Météo-France - Centre National de la Recherche Scientifique, Toulouse, France \\ Received: 18 June 2010 - Revised: 8 September 2010 - Accepted: 27 October 2010 - Published: 27 April 2011
}

\begin{abstract}
In the Northwestern Mediterranean region, large amounts of precipitation can accumulate over the coasts in less than a day. The present study aims at characterising the origin and the pathways of the moisture feeding such heavy precipitation. The ten Heavy Precipitating Events (HPEs) that occurred over the French Mediterranean region during the autumns of 2008 and 2009 are simulated with the nonhydrostatic research numerical model Meso-NH at $2.5 \mathrm{~km}$, $10 \mathrm{~km}$ and $40 \mathrm{~km}$ horizontal resolution.

Using eulerian on-line passive tracers, high-resolution simulations $(2.5 \mathrm{~km}$ horizontal resolution) show that the heavy precipitating systems are fed by a south-southwesterly to easterly low-level moist flow. It is typically $1000 \mathrm{~m}$ deep and remains almost unchanged all along an event. This lowlevel feeding flow crosses the most northwestern part of the Mediterranean in 5 to $10 \mathrm{~h}$.

Larger-scale simulations $(40 \mathrm{~km}$ and $10 \mathrm{~km}$ horizontal resolution) show that the moisture of the low-level feeding flow is provided by both evaporation of the Mediterranean Sea within the last 2 days before the HPE triggering and transport from remote sources in the lower half of the troposphere over more than 3 to 4 days. Local Mediterranean moisture is gained along the air mass low-level progress towards the Northwestern Mediterranean basin following two main branches along the Spanish coast and west of Sardinia. The Mediterranean Sea is the main moisture source when anticyclonic conditions prevail during the last 3 or 4 days before the HPE. When cyclonic conditions prevail before the HPE, the relative contribution of local and remote sources is more balanced. Remote moisture comes most of the time from the Atlantic Ocean. African tropical moisture is a less frequent but larger remote source.
\end{abstract}

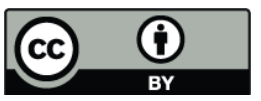

Correspondence to: F. Duffourg

(fanny.duffourg@meteo.fr)

\section{Introduction}

The Northwestern Mediterranean region is regularly affected by heavy precipitation often causing devastating flash-floods. Most of the coastal areas of the region are concerned: the Eastern Spanish coast (Peñarrocha et al., 2002), Southern France (e.g. Aude 1999 event Ducrocq et al., 2003, Gard 2002 event Ducrocq et al., 2004; Delrieu et al., 2005) and Northwestern Italy (e.g. Piedmont 1994 and 2000 events Buzzi et al., 1998; Turato et al., 2004).

Heavy Precipitating Events (HPEs) in the Northwestern Mediterranean region are due to either a frontal precipitating system or a Mesoscale Convective System (MCS), or a combination of both. In some cases, large amounts of precipitation accumulate quite slowly over more than a day when a frontal system slows down leading large-scale precipitation to affect almost the same region. However, past studies have shown that for most of the HPEs, large rainfall amounts are recorded very rapidly when a quasistationary MCS persists over the same area for several hours (Rivrain, 1997; Romero et al., 2000; Nuissier et al., 2008). Such convective systems are backbuilding (Bluestein and Jain, 1985) and frequently take a typical V-shape on infrared satellite images (Scofield, 1985). New convective cells continuously generate at the $\mathrm{V}$ tip, whereas older ones are gradually transported towards the $\mathrm{V}$ branches and dissipate downstream.

The meteorological ingredients favouring these convective systems in the Northwestern Mediterranean region are highlighted as example in Nuissier et al. (2008) or in Homar et al. (2002). The key elements are a synoptic pattern inducing a moderate to strong southerly to easterly lowlevel flow that transports moist and unstable Mediterranean air masses towards the coast. Such moist and unstable air masses are obtained when the relatively warm Mediterranean Sea provides moisture and heat to the lowest levels of the atmosphere. This occurs mainly during the autumn. Some synoptic ingredients such as the divergence of the

Published by Copernicus Publications on behalf of the European Geosciences Union. 
upper-level flow or upper-level potential vorticity anomalies and pressure lows can also help to destabilise the air mass and enhance the convection (Homar et al., 1999; Massacand et al., 1998; Nuissier et al., 2008; Tripoli et al., 2007). The conditional convective instability within the low-level flow can be released through the lifting induced either by the impinging of the mountain ranges surrounding the coast, or the local convergence of the flow induced by the orography of the region, or cyclogeneses. A low-level cold pool possibly formed under the MCS can also force the lowlevel flow to lift at its leading edge, favouring the release of the conditional convective instability (Ducrocq et al., 2008). Finally, to become quasi-stationary, these convective systems require the large-scale environment to evolve slowly enabling the convective cells to form at the same location for several hours (Homar et al., 2002).

The extreme rainfall observed during an HPE requires large amounts of moisture to feed the precipitating system. Regarding the origin of these large amounts of moisture, the partition between the local source for moisture (Mediterranean Sea) and other remote sources as well as the pathways and time scale of moisture transport are still open questions. Several past studies (Krichak and Alpert, 1998; Reale et al., 2001; Turato et al., 2004) have investigated this issue for specific case studies. They found a quite large contribution of tropical moisture coming either from the African ITCZ (InterTropical Convergence Zone) or from the extratropical remnants of Atlantic tropical cyclones. Turato et al. (2004) evaluated that only $20 \%$ of the moisture involved in the 2000 Piedmont flood originated from local Mediterranean sources. The main source for this HPE appeared to be the Eastern Atlantic Ocean. The time scale of the moisture transport towards the precipitation area was assessed to be about 2 days for local sources, 2-5 days for contributions from the Eastern Atlantic Ocean and the African ITCZ and a week or more for extratropical Atlantic cyclone transitions.

These past studies all addressed the question focusing on a single HPE. The purpose of this paper is to broaden the scope of these previous studies by systematically studying all the HPEs that occurred during two successive falls over a particular Mediterranean region. The region chosen for this study is the Southeastern France, known to be frequently affected by HPEs (Nuissier et al., 2008). The origins of the HPE moisture supply and the pathways of moisture transport are diagnosed by a downscaling of the ERA-Interim reanalyses based on nested numerical simulations starting four days prior to the HPE. The diagnostic is refined for the day of the HPE using convective-scale analyses and simulations. The experimental design is described in Sect. 2. The relevance of the method used to diagnose the moisture origin is validated in Sect. 3. Section 4 highlights the common characteristics of the moisture feeding inflow while Sect. 5 details its remote origin and the features of the moisture transport. Conclusions are drawn in Sect. 6.

\section{Experimental design}

\subsection{Numerical simulations}

The origin of the moisture feeding the Mediterranean HPEs is analysed through numerical simulations performed with the French research model Meso-NH (Lafore et al., 1998). Meso-NH is a nonhydrostatic mesoscale numerical model. The prognostic variables are the three Cartesian components of velocity, the dry potential temperature, the six water mixing ratios - water vapour, cloud water, rain water, primary ice, snow aggregates, and graupel - and the Turbulent Kinetic Energy (TKE). The prognostic equations of the six water species are governed by a bulk 1-moment mixed microphysical scheme (Caniaux et al., 1994; Pinty and Jabouille, 1998) combining a three-class ice parametrisation with a Kessler's scheme for the warm processes. The turbulence parametrisation is one-dimensional, based on a 1.5-order closure (Cuxart et al., 2000) of the TKE equation. The mixing length is defined in agreement with Bougeault and Lacarrère (1989). The shallow convection is parametrised according to a peculiar EDMF (Eddy Diffusivity Mass Flux) scheme described in Pergaud et al. (2009). When Meso-NH is run with an horizontal resolution coarser than $10 \mathrm{~km}$, the subgridscale deep convection is parametrised with the Kain and Fritsch scheme (Kain and Fritsch, 1993). The long-wave radiative scheme is the RRTM (Rapid Radiation Transfer Model) parametrisation (Mlawer et al., 1997) of ECMWF. The surface exchanges of energy and water are computed as weighted average of the fluxes given by four different surface schemes running for the different surface types (natural land surface, urban area, ocean and lake) encountered in each grid mesh. The natural land surfaces are handled by the ISBA (Interactions Soil-Biosphere-Atmosphere) scheme (Noilhan and Mahfouf, 1996). The energy exchanges over urban surfaces are parametrised according to the TEB (Town Energy Balance) scheme (Masson, 2000) and the turbulent air-sea fluxes with the ECUME parametrisation (Belamari, 2005). The vertical grid is defined with 40 vertical stretched levels (Gal-Chen and Somerville, 1975). Rayleigh damping is progressively applied above $15 \mathrm{~km}$ altitude up to the top of the model at $20 \mathrm{~km}$ in order to prevent spurious reflections from the upper boundary.

For each studied HPE, two numerical simulations are performed. First, a convective-scale simulation initialized with a fine-scale analysis just before the event provides the best possible representation of the precipitating systems and their short-range moisture supply. Then, to analyse the moisture transport over a longer period before the HPE triggering, two-way nested mesoscale simulations that downscale large-scale re-analyses, are started 4 days prior to the event over a larger domain. A $40-\mathrm{km}$ resolution domain encompassing the whole Mediterranean Sea and the Eastern Atlantic Ocean allows to search for the large-scale 
remote sources of moisture over these areas, while a 10 $\mathrm{km}$ resolution domain nested in the $40-\mathrm{km}$ one permits to describe the mesoscale dynamical adaptation of the largescale flow to the orography lining the Western Mediterranean Sea. Thus, the strong influence of the typical orography of the region on the moisture transport over the Western Mediterranean Sea, such as chanelling or Foehn effects, lee cyclogeneses, etc. is represented in our simulations.

The convective-scale simulations are performed on a $625 \times 560 \mathrm{~km}$ domain covering the Northwestern Mediterranean with a $2.5 \mathrm{~km}$ horizontal resolution (cf. Fig. 1). These simulations are hereafter called HRA2.5. For each study case, the convective-scale simulation is initialized between 2 and $7 \mathrm{~h}$ before the first convection triggering characterised by rainfall radar reflectivities exceeding $35 \mathrm{dBz}$ to $40 \mathrm{dBz}$. The onset of convection thus comes after the model precipitation spin-up. The simulation runs till the end of the precipitating event, i.e. during 18 to $36 \mathrm{~h}$ depending on the event. The initial and lateral boundary conditions are provided by the convective-scale AROME (Application of Research to Operations at MEsoscale) analyses (Ducrocq et al., 2005; Yan et al., 2009). These analyses are produced by the 3-hourly 3D-var data assimilation cycle of the AROME operational numerical prediction system at $2.5 \mathrm{~km}$ horizontal resolution over France. All conventional observations are assimilated by AROME (surface observations from land stations and ships, vertical soundings from radiosondes and pilot balloons, buoy and aircraft measurements), together with wind profilers, winds from AMV (Atmospheric Motion Vectors) and scatterometers, Doppler winds from radars, satellite radiances and ground-based GPS (Global Positioning System) measurements.

The larger-scale nested simulations start 4 days before the HPE triggering. This set of simulations is called RAIxx, $\mathrm{xx}$ being the resolution of the domain. The $40-\mathrm{km}$ resolution grid (cf. Fig. 1) of RAI40 covers all Europe, Eastern Atlantic, the Mediterranean Sea and Northern Africa. Its initial and boundary conditions are provided by the ERAInterim reanalyses (Simmons et al., 2007). These recent reanalyses offer an improved description of the atmospheric humidity field (Uppala et al., 2008). The 10-km resolution domain (RAI10), covering Western Europe, Maghreb and the Western Mediterranean Sea, is two-way nested in the 40$\mathrm{km}$ domain. The coarser grid provides the lateral boundary conditions to the finer grid, while the variables of the coarser grid are relaxed with a short relaxation time towards the finer grid values in the overlapping area (Stein et al., 2000). The last day before the HPE, a third two-way nested domain at $2.5 \mathrm{~km}$ resolution (RAI2.5) is added in order to ease the comparison between this set of simulations and the HRA2.5 ones.

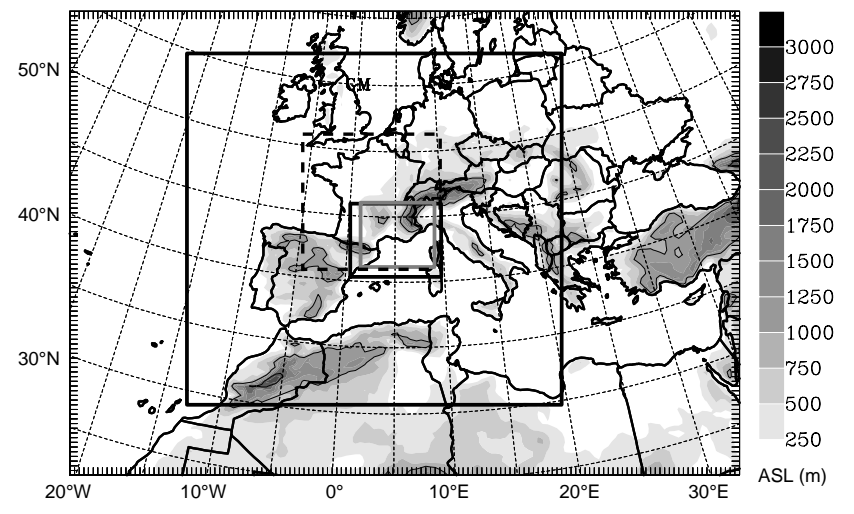

Fig. 1. Domains of the HRA2.5 (in solid grey) and RAI (in solid black) simulations. The boundaries of the AROME model are drawn with dashed black lines. The orography is displayed in grey scale with a solid contour at the $1000 \mathrm{~m}$ and $2000 \mathrm{~m}$ levels.

\subsection{Analysis tools}

The convective-scale simulations are used to analyse the moisture supply to the heavy precipitating systems, using the lagrangian analysis tool of Gheusi and Stein (2002) based on eulerian on-line passive tracers. All the modelled transport processes, which are the advection by the explicitely resolved fluid motions and the transport by subgrid turbulent and convective motions, are considered so that the motions captured by the eulerian tracers correspond exactly to the model dynamics. The transport processes are calculated at every time step and at the model grid points avoiding any time or spatial interpolation of the model wind field as necessitated by the classical off-line lagragian trajectory tools (e.g. among others, FLEXPART, Stohl and James, 2004). This analysis is performed for the different phases of the simulated HPEs determined from the rainfall radar reflectivities and the hydrometeor content of the simulated precipitating systems: precipitation initiation and convective or large-scale mature precipitation with possible distinctions according to the presence and position of a frontal system. The dissipation and/or evacuation phase is not considered because this phase is likely not enough steady and representative of the moisture supply to the heavy precipitating systems. To identify the origin of the air mass feeding the heavy precipitating systems, a few lagrangian parcels are selected inside the ascents of the HRA2.5 simulated precipitating systems either near the middle of the troposphere (4-6 km) for non-convective precipitation or during the convection initiation phase, or near the tropopause $(9-10 \mathrm{~km})$ for the convective mature phase. The air parcels are tracked backwards within the HRA2.5 simulations as long as they remain in its $2.5 \mathrm{~km}$ domain and at the latest till $3 \mathrm{~h}$ after the HRA2.5 simulation beginning. To characterise the moisture supply, additional diagnostics are computed such as a $3 \mathrm{~km}$-depth vertically integrated moisture flux 
Table 1. The HPE cases. For the region affected by the HPEs, CV stands for the Cévennes-Vivarais region, R for Roussillon and SA for Southern Alps (see Fig. 2 for their geographical locations).

\begin{tabular}{rcccr}
\hline \multicolumn{1}{c}{ Date } & $\begin{array}{c}\text { Region } \\
\text { affected }\end{array}$ & $\begin{array}{c}\text { Hour of the first } \\
\text { convective cells }\end{array}$ & $\begin{array}{c}\text { Initial time for } \\
\text { HRA simulations }\end{array}$ & $\begin{array}{c}\text { Initial time for } \\
\text { RAI simulations }\end{array}$ \\
\hline 12 Aug 2008 & CV & 06:00 UTC & 00:00 UTC & 8 Aug 00:00 UTC \\
3 Sep 2008 & CV & 08:00 UTC & 06:00 UTC & 30 Aug 06:00 UTC \\
20 Oct 2008 & CV & 06:00 UTC & 00:00 UTC & 16 Oct 00:00 UTC \\
21 Oct 2008 & CV & 07:00 UTC & 00:00 UTC & 17 Oct 00:00 UTC \\
1 Nov 2008 & CV & 10:00 UTC & 06:00 UTC & 28 Oct 06:00 UTC \\
8 Oct 2009 & CV & 11:00 UTC & 06:00 UTC & 4 Oct 06:00 UTC \\
20 Oct 2009 & CV & 06:00 UTC & 00:00 UTC & 16 Oct 00:00 UTC \\
18 Sep 2009 & SA & 03:00 UTC & 00:00 UTC & 14 Sep 00:00 UTC \\
22 Oct 2009 & SA & 09:00 UTC & 06:00 UTC & 18 Oct 06:00 UTC \\
26 Dec 2008 & R & $04: 00$ UTC & 00:00 UTC & 22 Dec 00:00 UTC \\
\hline
\end{tabular}

$\boldsymbol{Q}=\int_{0}^{z=3 \mathrm{~km}} \rho_{\mathrm{v}} \boldsymbol{v}_{\mathrm{h}} d z$ (where $\rho_{\mathrm{v}}$ is the specific humidity and $\boldsymbol{v}_{\mathrm{h}}$ the horizontal wind vector), the Convective Available Potential Energy (CAPE) and the levels of condensation, of free convection and of neutral buoyancy. The evolution of the parcel water vapour mixing ratio and relative humidity along their trajectories is also examined.

The backward trajectories based on the HRA2.5 simulations help to characterise the moist inflow feeding the heavy precipitating systems and identify the short-range origin of moisture. The remote origin of the moist feeding flow and the tracks of the moisture transport over the last 4 days before the HPE are then studied with the RAI40 and RAI10 simulations. For that, it is verified that the short-range moisture origin area has similar characteristics in terms of moisture and winds in both the RAI and the HRA2.5 simulations to allow a continuity between the short-range and mediumrange investigations. Then, new lagrangian parcels are selected at the position of the end of the HRA2.5 backward trajectories to sample the short-range moisture origin area within the RAI10 simulation. These parcels are tracked backwards with the $10 \mathrm{~km}$ simulation as long as they remain in its domain and at the latest till $3 \mathrm{~h}$ after the simulation beginning - i.e. over about 4 days. If the parcels go rapidly out of the RAI10 domain, similar backward trajectories are performed with the RAI40 simulation. The evolution of the parcel thermodynamic characteristics is analysed all along the trajectories.

\subsection{Events selection}

The origin of the moisture feeding the Mediterranean HPEs is analysed for all the HPEs that occurred in Southeastern France (excluding Corsica) during the autumns of 2008 and 2009. HPEs are defined in this study as the days for which one of the station of the Méteo-France daily raingauge network recorded more than $150 \mathrm{~mm}$ in $24 \mathrm{~h}$. The spatial resolution of the daily raingauge network is sufficiently dense (148 stations per $10000 \mathrm{~km}^{2}$ and more than a thousand stations all over the Southeastern French Mediterranean region) to capture all the significant rainy events over the region. Also, the time period for selecting the cases is not strictly limited to the fall months but extends from August to January. This period gathers about $80 \%$ of the HPEs occuring over this region according to the 40-year climatology established by Ricard et al. (2010).

The selection applies only to the 2008 and 2009 years because the AROME convective-scale analyses used as initial and boundary conditions for the HRA2.5 simulations are computed operationally only since autumn 2008. According to these selection criteria, ten cases with observed HPEs are selected. They are listed in Table 1. Their geographical location is indicated together with the time of the first convective developments (rainfall radar reflectivities exceeding $35 \mathrm{dBz}$ to $40 \mathrm{dBz}$ ). The initialization times of the HRA2.5 and RAI40/10 simulations are also given following the experimental set-up described in Sect. 2.1. All the French regions most frequently exposed to HPEs (Nuissier et al., 2008) are represented in our simulated HPE sample. For every case except the 26 December 2008 one, precipitation is mainly produced by convective precipitating systems extending up to the tropopause. On the contrary, the large amounts of precipitation of the 26 December 2008 event are due to a long-lasting non-convective shallow precipitating system (not shown).

\section{Experimental design validation}

Before using the numerical simulations to perform a detailed analysis of the moisture sources for HPEs, a prerequisite is that the selected situations are also HPE-conducive in the "model world". In other words, it should be verified that the convective-scale simulations produce also significant precipitation amounts so that the simulated mesoscale environment can be considered as representative of an 
HPE-conducive environment. A perfect matching with the observed HPE is not required as the moisture transport and origin will be studied with respect to the simulated HPEs only.

Figure 2 shows the geographical location of the maximum daily precipitation simulated by HRA2.5 for all ten cases. The HRA2.5 simulations do produce quite heavy precipitation (at least $100 \mathrm{~mm}$ in $24 \mathrm{~h}$ ) for all the cases except for the 8 October 2009 one.

Figures 3-5 compare the HRA2.5 simulated and observed 24-h accumulated precipitation for the ten cases. The HRA2.5 simulation for the 1 November 2008 event compares very well to the observations with relatively well estimated amounts of precipitation and a very realistic rainfall pattern. For the other events, the HRA2.5 simulations show larger errors in location or in intensity of the rainfall amounts compared to the observations. The HRA2.5 simulated daily rainfall is overestimated for the 12 August 2008 and 20 October 2009 and is underestimated for every other event. The simulations for the 20 October 2009 and the 26 December 2008 are of good quality regarding the precipitating pattern over the Roussillon and CévennesVivarais regions, respectively. The underestimation of the maximum rainfall amounts is most of the time due to the lesser stationarity of the precipitating systems simulated with HRA2.5 in comparison with the observed ones. HRA2.5 thus produces less focused (e.g. 21 October 2008 case) and/or shorter lasting (e.g. 26 December 2008 case) precipitation. For the 8 October 2009 case, HRA2.5 clearly fails in simulating the small isolated MCS that stayed over a specific narrow area during $12 \mathrm{~h}$. The simulated precipitating system evolves more rapidly and dissipates earlier giving the weakest maximum of 24-h accumulated precipitation (about $90 \mathrm{~mm}$ ) of the ten cases. The RAI2.5 simulations are less realistic than the HRA2.5 ones with a larger underestimation of the 24-h accumulated precipitation. The heaviest precipitating area simulated by HRA2.5 is within $50 \mathrm{~km}$ of the observed one for the 12 August 2008, 21 October 2008, 1 November 2008, 20 October 2009 and 26 December 2008. Even for the other cases, the error does not exceed $100 \mathrm{~km}$. The simulated heaviest precipitation is always located within the same CV (Cévennes-Vivarais), R (Roussillon) or SA (Southern Alps) region as the observed one, i.e. in areas exposed to the southerly to easterly moist flow. Thus, all the HRA2.5 simulations, and even those producing less than $150 \mathrm{~mm}$, reproduce, for a few hours at least, steady and/or intense convective or larger-scale precipitating systems reasonably resembling those observed during an HPE. It makes thus sense to study the moisture inflow feeding these simulated systems to characterise the moisture supply of HPEs.

The continuity between the short-range analysis based on HRA2.5 and the longer-range one based on RAI10/RAI40 has also been assessed by verifying that the area identified as the short-range origin of the low-level moist feeding

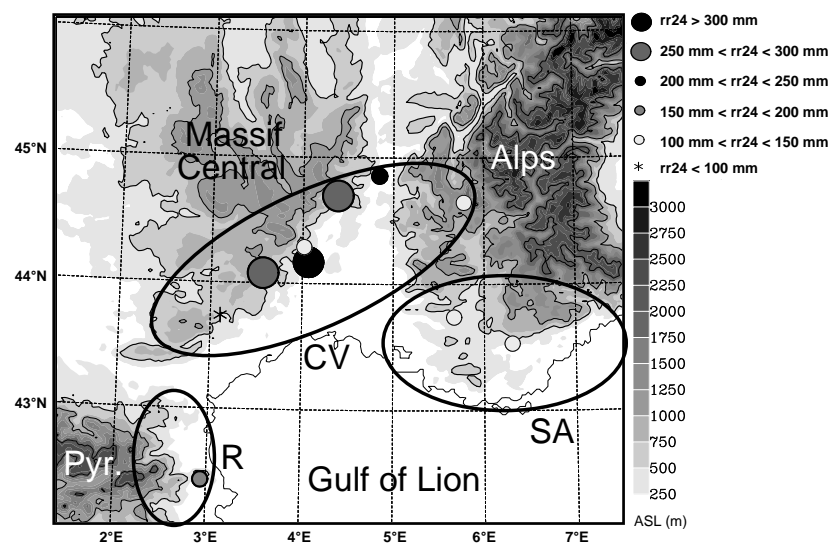

Fig. 2. Location and intensity of the maximum daily precipitation (rr24, top right legend) simulated with HRA2.5 for all the studied cases. The orography is displayed in grey scale (bottom right legend) with a bold solid contour at $500 \mathrm{~m}$ and a thin contour at $1 \mathrm{~m}$ (coastline), $1000 \mathrm{~m}$ and $2000 \mathrm{~m}$. The names of the main mountain ranges and of the the regions affected by the HPEs are also given. Pyr. stands for the Pyrenees, CV for the Cévennes-Vivarais region, $\mathrm{R}$ for Roussillon and SA for Southern Alps.

flow featured with the HRA2.5 simulations has the same characteristics in terms of humidity and winds in the RAI simulations. Most of the time, this moist flow is found very similar between the HRA2.5 and the RAI2.5 simulations. It is illustrated for the 12 August 2008 case in Fig. 6. Although the RAI2.5 simulation is slightly drier than the HRA2.5 one, both the low-level winds and the low-level water vapour fluxes are consistent.

\section{Characterisation of the moisture inflow}

The moisture inflow entering the simulated precipitating systems is identified and analysed using the HRA2.5 simulations. Figures 7-9 show the backward trajectories for some air parcels taken in the upper part of the precipitating systems during the mature stage of all the ten cases. The right panels display a projection of these backward trajectories on a vertical cross-section along the A-B axis shown in the left panels.

For all the convective cases - that means all the cases except for the 26 December 2008 one - the parcels originate mainly from the lowest $1000 \mathrm{~m}$ of the troposphere before being strongly lifted up to the upper troposphere by the convective ascents. In the 26 December 2008 event, the vertical extent of the precipitating system is limited to the lower half of the troposphere. The precipitating system of this event is embedded in a large-scale moist disturbance with a pressure low centred over the Gulf of Lion and a frontal system moving westwards towards the Roussillon coast (not shown). The lowest part of this moist disturbed air mass, up to about $3000 \mathrm{~m}$, feeds the precipitating system as shown in Fig. 9. 


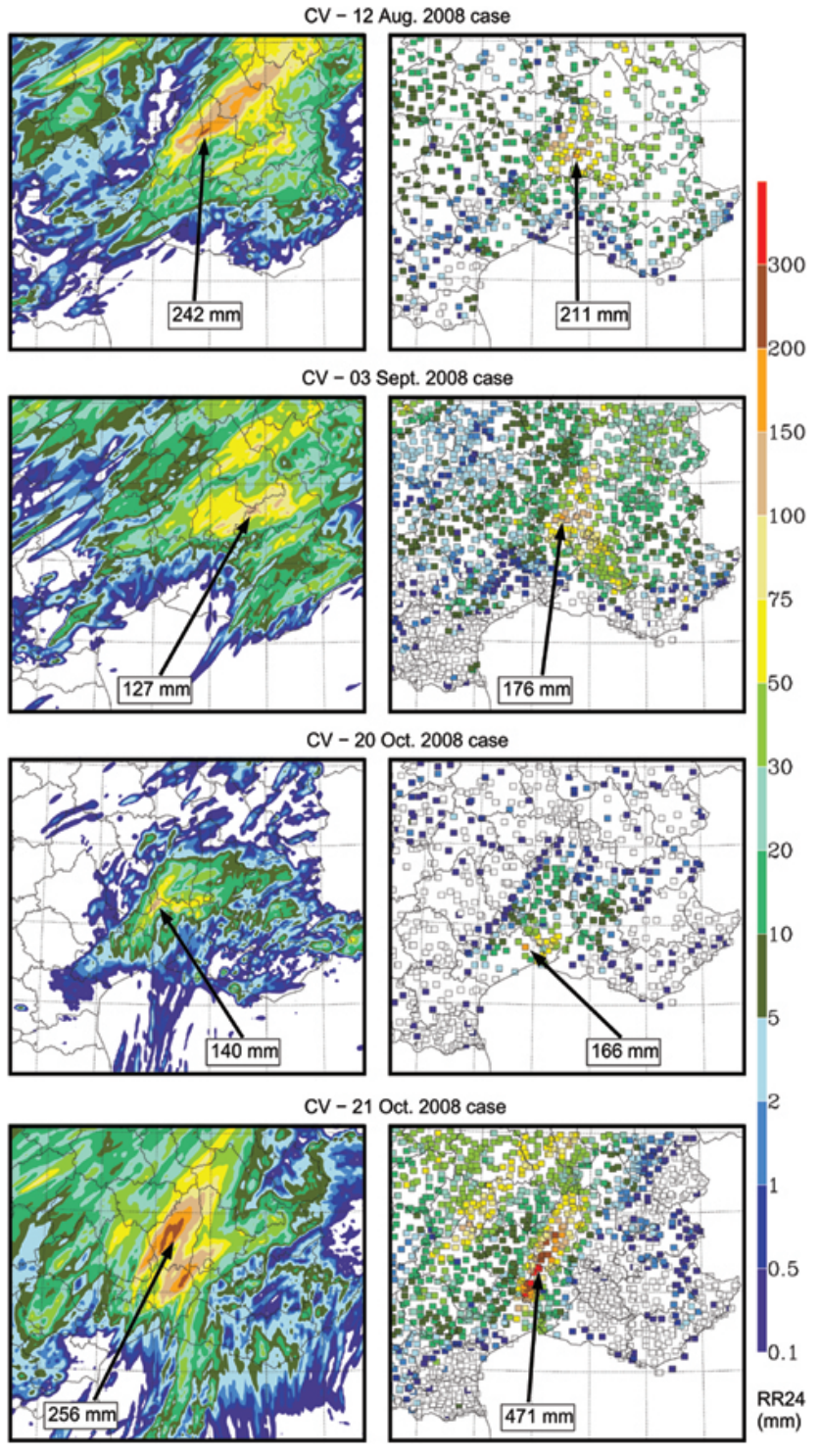

Fig. 3. 24-h accumulated precipitation ( $r 24$ in $\mathrm{mm}$ ) from the HRA2.5 simulations (left panels) and the Météo-France rain-gauge network (right panels) at 00:00 UTC, 13 August 2008 for the 12 August 2008 case (top), at 06:00 UTC, 4 September 2008 for the 3 September 2008 case (middle top), at 00:00 UTC, 21 October 2008 for the 20 October 2008 case (middle bottom) and at 06:00 UTC, 22 October 2008 for the 21 October 2008 case (bottom). The maximum of precipitation is indicated on each panel.

For all the cases, the low-level pathway of the parcels is mostly over the Mediterranean Sea. Depending on the intensity of the low-level flow, the parcels take from 5 to $10 \mathrm{~h}$ to cross the most northwestern part of the Mediterranean basin. Contrary to the other cases, 8 October 2009 is associated with a weak low-level flow which explains the shorter pathway of the trajectories. All along their pathway over the sea, the parcels stay almost at the same level.
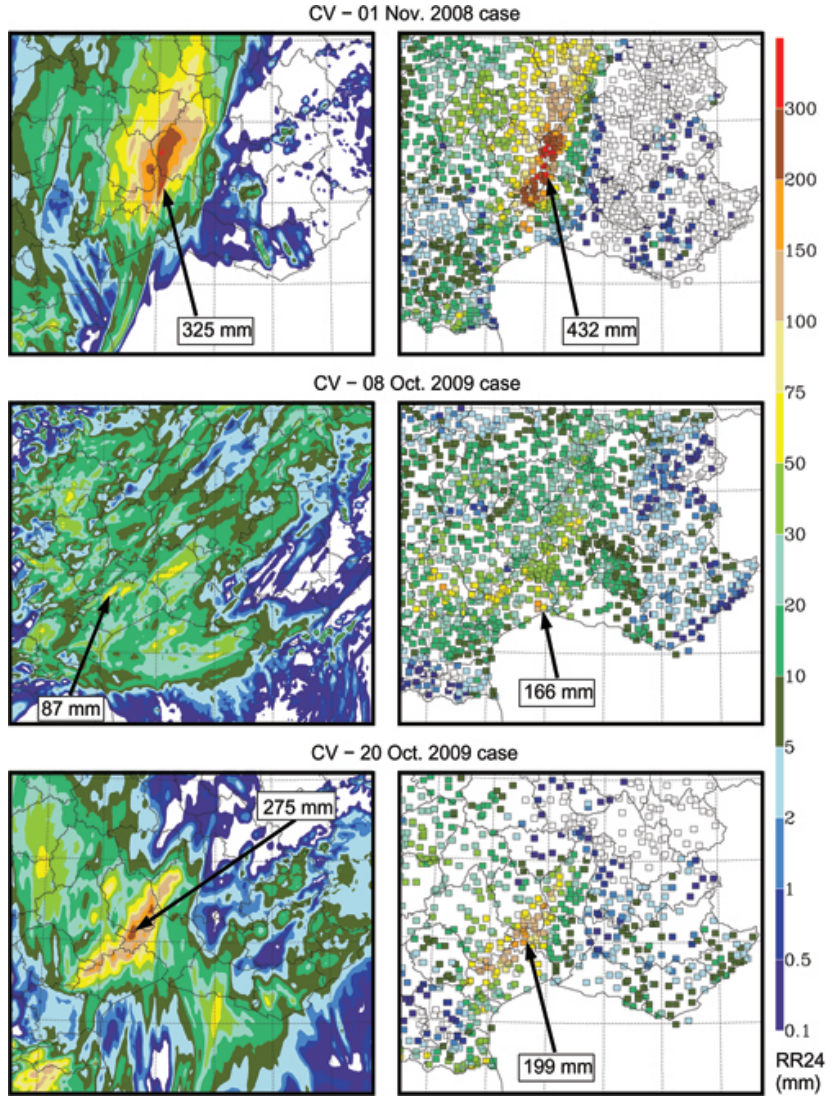

Fig. 4. Same as Fig. 3, but at 06:00 UTC, 2 November 2008 for the 1 November 2008 case (top), at 06:00 UTC, 9 October 2009 for the 8 October 2009 case (middle) and at 12:00 UTC, 21 October 2009 for the 20 October 2009 case (bottom).

For all the convective cases, the depth of the lowlevel marine inflow as diagnosed by the vertical extent of the backward trajectories is linked with the depth of the conditionally unstable low-level layer. Figure 10 shows for three cases - 12 August 2008, 21 October 2008 and 18 September 2009 - the mean thermodynamic characteristics of the low-level inflow. The potential temperature, the equivalent potential temperature and the water vapour mixing ratio vertical profiles have been averaged over about $150 \mathrm{~km} \times 60 \mathrm{~km}$ boxes (shown in Figs. 7 and 9) to derive the mean characteristics of the low-level inflow. The grey zones in Fig. 10 delimit for each case, the layer of conditionally unstable air, i.e. the layer with a CAPE larger than $100 \mathrm{~J} \mathrm{~kg}^{-1}$. The mean relative humidity of this unstable layer is also given in Fig. 10. The conditionally unstable boundary layer is shallow for the 12 August 2008 case whose feeding inflow as identified by the backward trajectories is confined in the lowest $200 \mathrm{~m}$ of the troposphere (see Fig. 7). For the 21 October 2008 and the 18 September 2009 cases, the conditionally unstable layer is vertically more extended, in agreement with the depth of the feeding inflow which extends up to $600 \mathrm{~m}$ and $900 \mathrm{~m}$, respectively (see Figs. 7 and 9). 

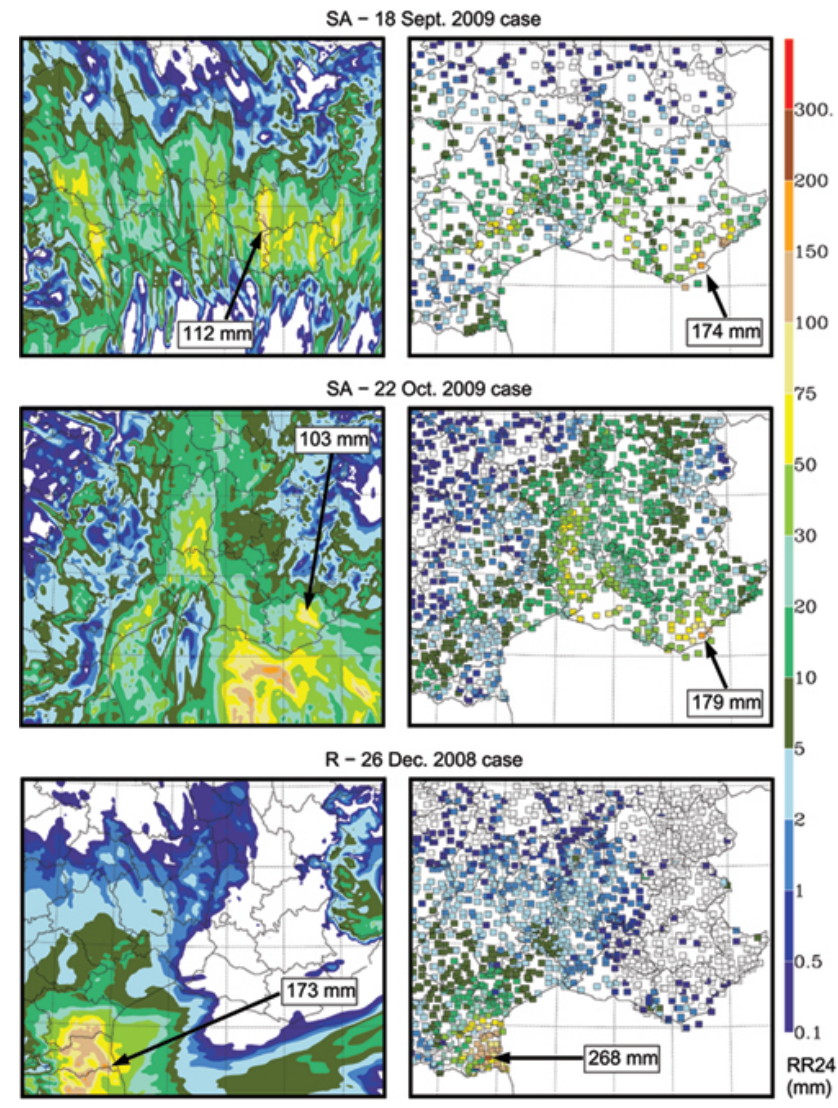

Fig. 5. Same as Fig. 3, but at 00:00 UTC, 19 September 2009 for the 18 September 2009 case (top), at 06:00 UTC, 23 October 2009 for the 22 October 2009 case (middle) and at 06:00 UTC, 27 December 2008 for the 26 December 2008 case (bottom).
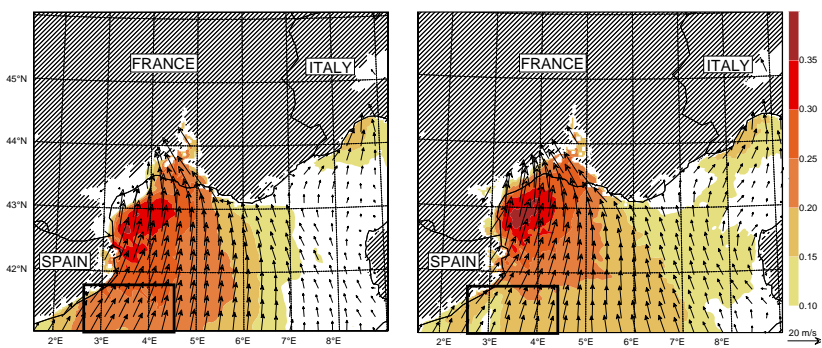

Fig. 6. Water vapour flux (in $\mathrm{kg} \mathrm{s}^{-1}$, colour scale on the right of the figure) and wind vector at $100 \mathrm{~m}$ a.s.l. at 03:00 UTC, 12 August 2008, for both the HRA2.5 simulation (left panel) and the RAI2.5 one (right panel). Wind arrows are drawn every 10 grid points with a scale in $\mathrm{m} \mathrm{s}^{-1}$ given by the length of the arrow at the bottom right of the figure. The black rectangle delimits the moist feeding flow area. Model terrain higher than $100 \mathrm{~m}$ a.s.l. is hatched.

The low-level inflow diagnosed by the backward trajectories is quite moist as illustrated by Fig. 10 for the 12 August 2008, 21 October 2008 and 18 September 2009 cases (relative humidity around $80 \%$ or $90 \%$ ). It is consistent with the low-level winds and the low-level water vapour fluxes as shown by Fig. 11 for the 21 October 2008 and 26
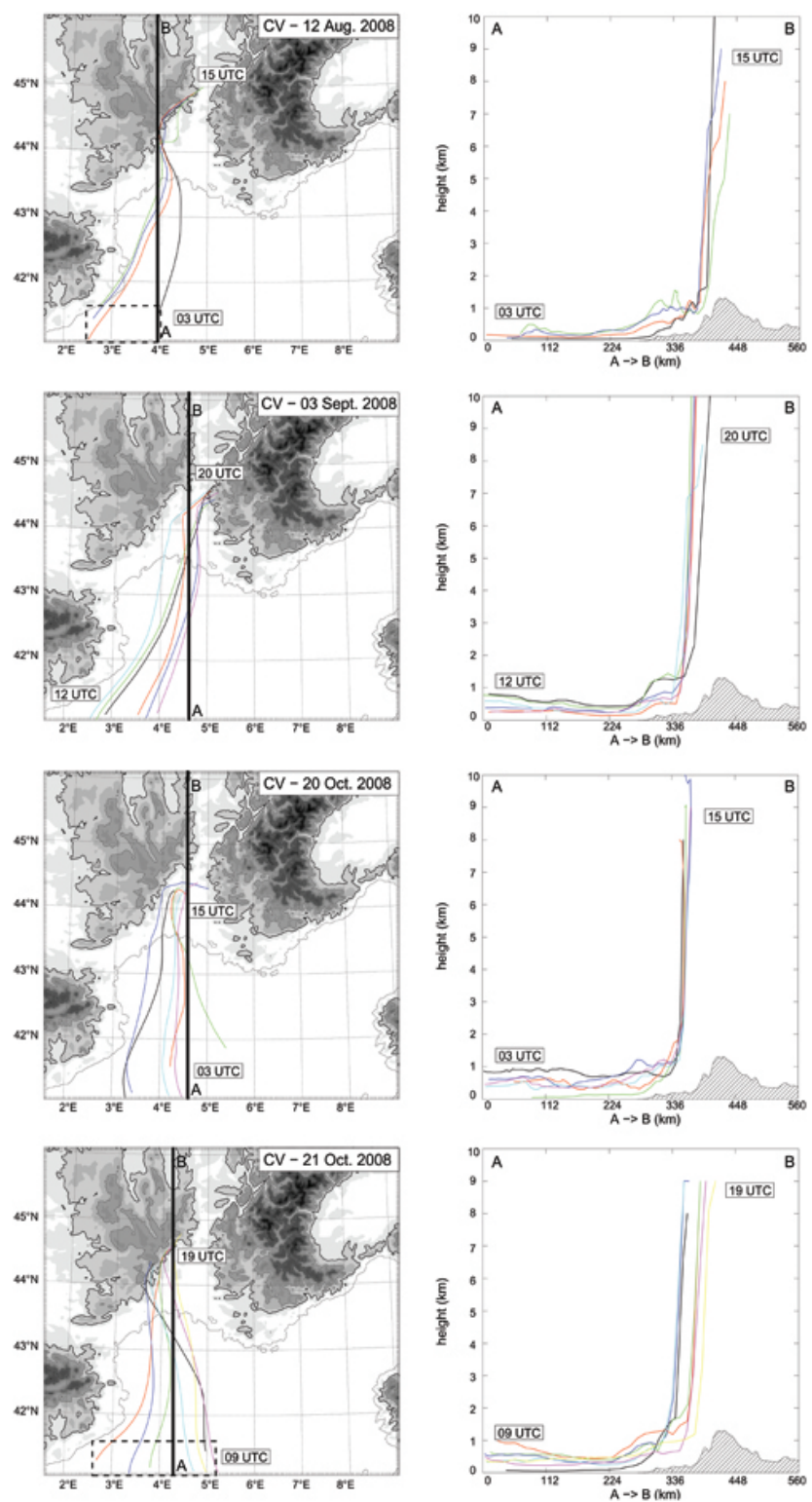

Fig. 7. Backward trajectories of some air parcels taken in the upper part of the precipitating systems simulated by HRA2.5 for four CV cases, the 12 August 2008 (top), the 3 September 2008 (middle top), the 20 October 2008 (middle bottom) and the 21 October 2008 (bottom) cases. The backward trajectories are projected both on an horizontal plane (left panels) and on a vertical cross-section (right panels). The vertical cross-section follows the line AB displayed on the left planels. The orography is superimposed in grey scale as in Fig. 2 for the left panels and as a hatched area for the right panels. The dashed rectangles in the top and bottom left panels delimit the areas used for the calculation of the average thermodynamic characteristics of the 12 August 2008 and 21 October 2008 lowlevel feeding inflow displayed Fig. 10.

December 2008 cases. The air parcels cross over the area of maximum of low-level integrated water vapour flux $\boldsymbol{Q}$ and follow its main direction. 

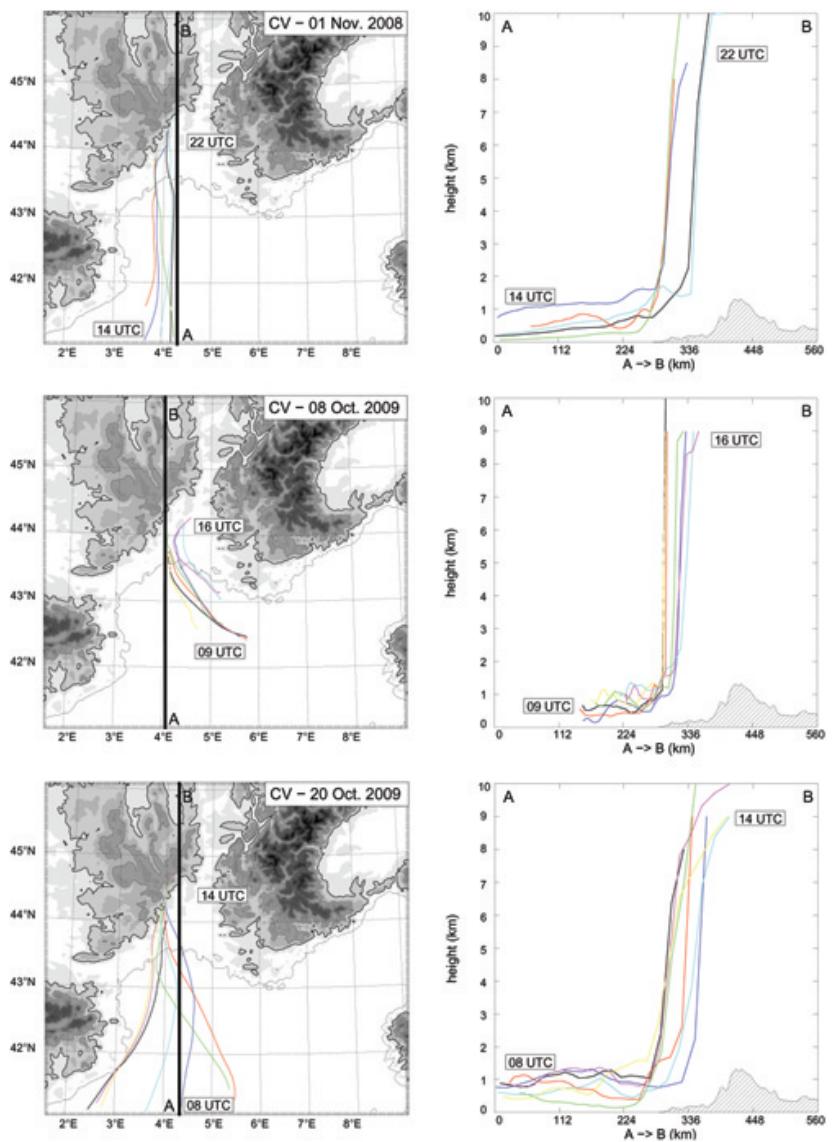

Fig. 8. Same as Fig. 7 for the last three CV cases, the 1 November 2008 (top), the 8 October 2009 (middle) and the 20 October 2009 (bottom).

In all the studied cases, the low-level feeding inflow gains less than $1 \mathrm{~g} \mathrm{~kg}^{-1}$ in the last hours when advancing over the Gulf of Lion towards the French Mediterranean coast. It already contains most of the water vapour when entering the most northwestern part of the Mediterranean Sea with water vapour mixing ratios ranging from $9 \mathrm{~g} \mathrm{~kg}^{-1}$ to $14 \mathrm{~g} \mathrm{~kg}^{-1}$ according to the event - except for the 26 December 2008 event whose inflow water vapour mixing ratio is only of about $3.5 \mathrm{~g} \mathrm{~kg}^{-1}$ because the air mass is much colder. All along their 5 to 10 -h pathway over the Gulf of Lion, the parcel relative humidity remains above $70 \%$ and most of the time above $80 \%$. The parcels reach saturation when lifted above $500 \mathrm{~m}$ to $1500 \mathrm{~m}$ according to their water vapour content.

The moist inflow feeding the precipitating systems does not much change during an event. The backward trajectories of air parcels taken in the precipitating systems remain very similar all along the initiation and mature phases as well as when a frontal disturbance passes through as illustrated for the 21 October 2008 case (Fig. 12). The vertical extent of the low-level feeding inflow is quite the same all along an event. Only a slight evolution can be seen in some cases as a light
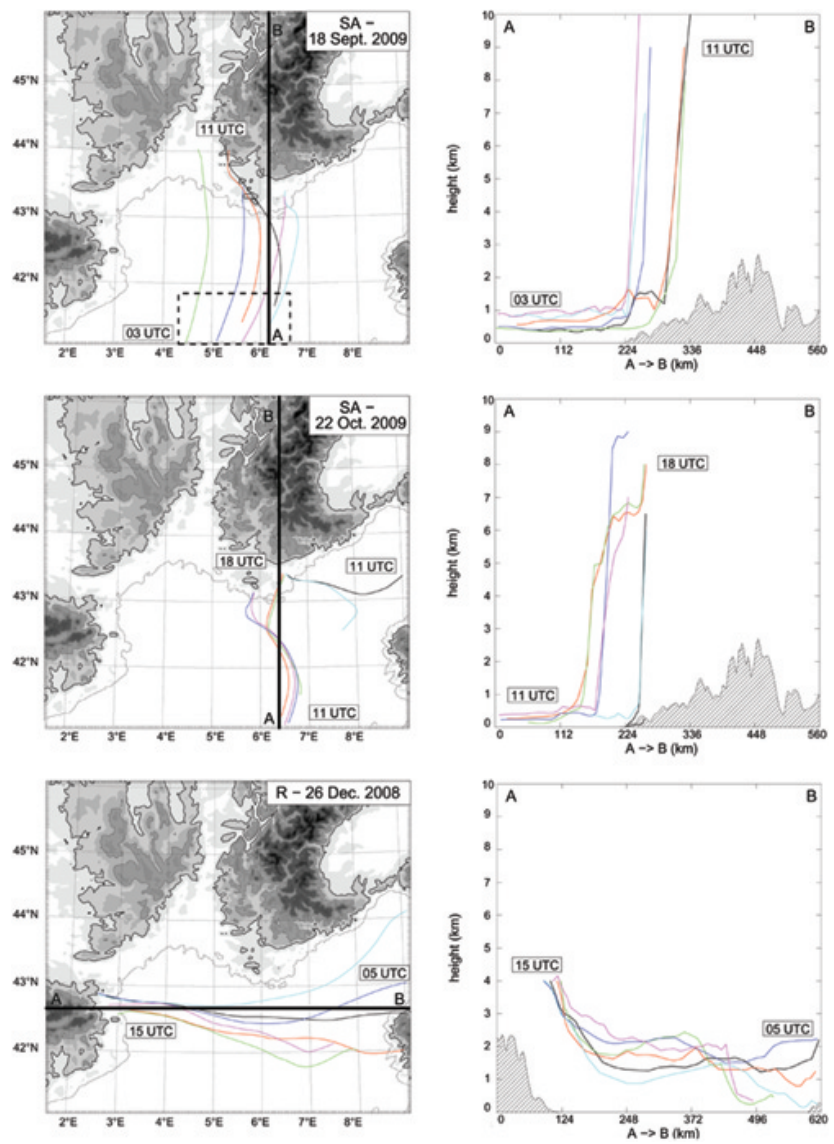

Fig. 9. Same as Fig. 7, but for the two SA 18 September 2009 (top) and 22 October 2009 (middle) cases and the 26 December 2008 Roussillon case (bottom). The dashed rectangle in the top left panel delimits the area used for the calculation of the average thermodynamic characteristics of the 18 September 2009 low-level feeding inflow displayed Fig. 10.

eastward shift for the 21 October 2008 and the 1 November 2008 cases or a southward shift for the 26 December 2008 case. It is not really surprising that the moist feeding inflow remains almost unchanged all along the life-cycle of a MCS, as a condition for recording high rainfall amounts is a rather slow-evolving environment. However, it is interesting to note that even for cases involving a frontal disturbance, the air parcels feeding the most active precipitation area keep founding their origins within the warm and moist conveyor belt ahead of the slowly evolving cold front.

It is clear from Figs. 7-9 that the parcel pathways over the Northwestern Mediterranean and the geographical location of the heavy precipitation are related. All Cévennes-Vivarais events, except the 8 October 2009 one, are fed with a similar more or less converging southerly low-level flow with parcel pathways extending from offshore Spanish Catalonia to the Gulf of Lion. In some cases, the southerly low-level feeding flow slightly shifts westwards when approaching the French coast. This is consistent with the results of 


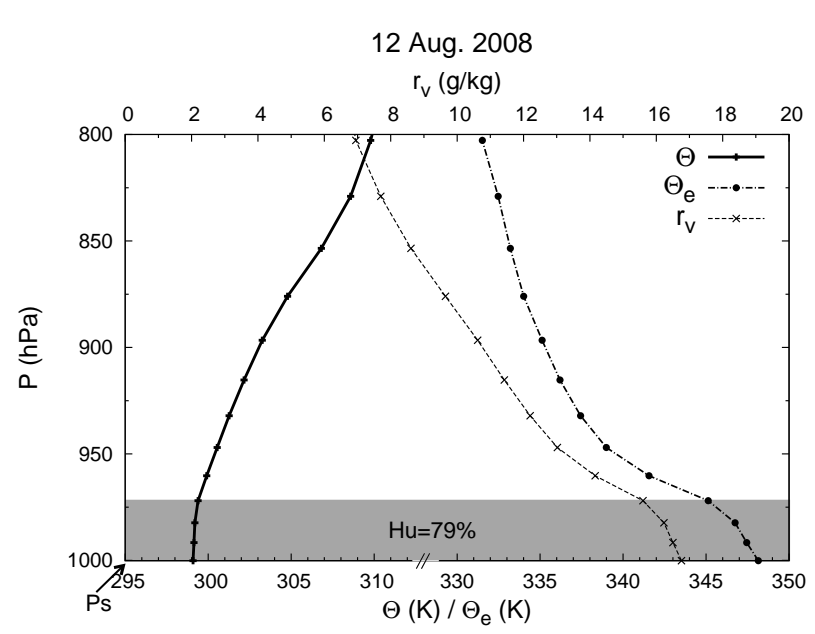

21 Oct. 2008

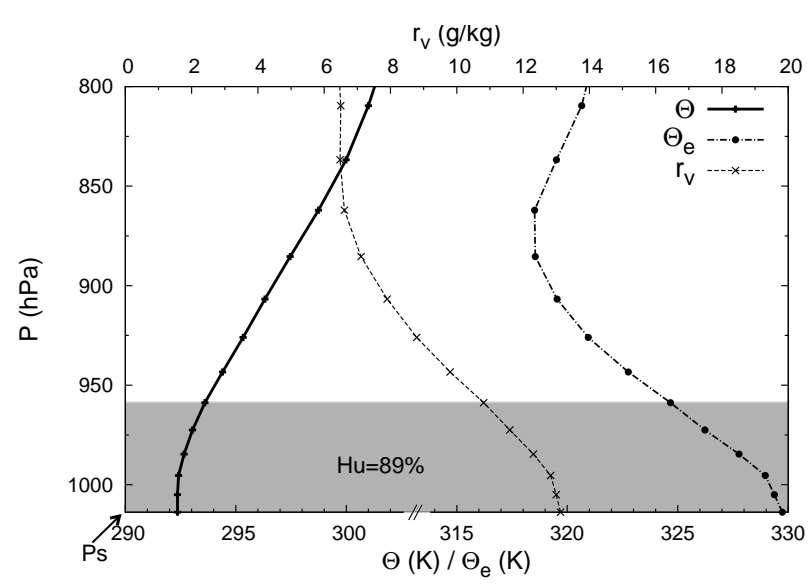

18 Sept. 2009

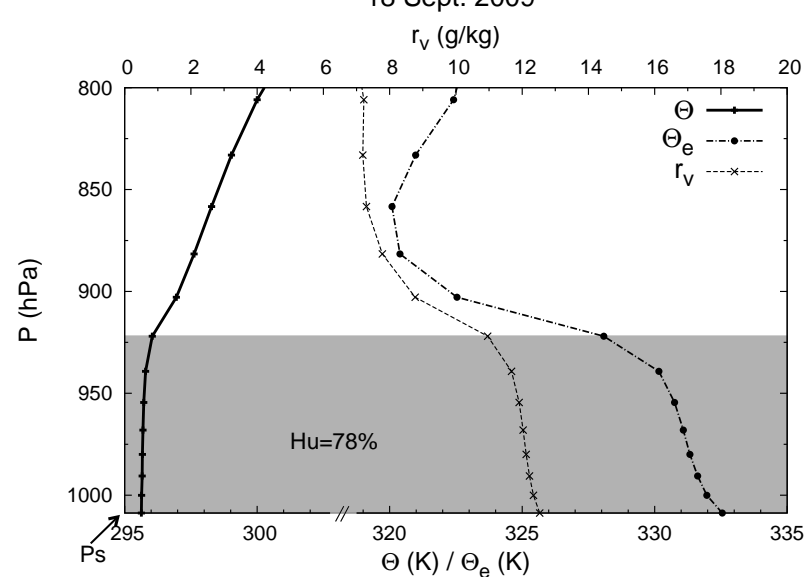

Fig. 10. Average potential temperature $(\theta$ in $\mathrm{K})$, equivalent potential temperature $\left(\theta_{\mathrm{e}}\right.$ in $\left.\mathrm{K}\right)$ and water vapour mixing ratio $\left(r_{\mathrm{V}}\right.$ in $\left.\mathrm{g} \mathrm{kg}^{-1}\right)$ profiles computed over the dashed boxes plotted in Figs. 7 and 9 for the three cases 12 August 2008 (top), 21 October 2008 (middle) and 18 September 2009 (bottom). The grey area represents the vertical extent of the conditionally unstable layer potentially involved in deep convection $\left(\mathrm{CAPE} \geq 100 \mathrm{~J} \mathrm{~kg}^{-1}\right.$ ). The mean relative humidity in this unstable layer is also given.
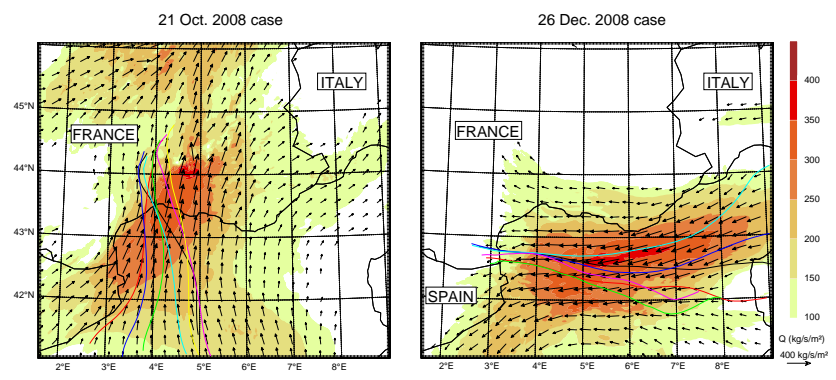

Fig. 11. HRA2.5 simulated water vapour flux $\boldsymbol{Q}$ integrated over the lowest $3000 \mathrm{~m}$ (in $\mathrm{kg} \mathrm{s}^{-1} \mathrm{~m}^{-2}$, colour scale on the right of the figure, and arrows) and horizontal projection of the backward trajectories of some air parcels taken in the precipitating systems simulated by HRA 2.5 for the 21 October 2008 case (left) and the 26 December 2008 case (right). The arrows are drawn every 10 grid points with a scale given by the length of the arrow at the bottom right of the figure. Arrows are displayed only when corresponding to values of integrated water vapour flux larger than $80 \mathrm{~kg} \mathrm{~s}^{-1} \mathrm{~m}^{-2}$. The backward trajectories are the same as in Figs. 7 and 9. They show the parcel trajectories from 09:00 UTC till 19:00 UTC for the 21 October 2008 case and from 05:00 UTC till 15:00 UTC for the 26 December 2008 case. The background of the trajectory figure is a snapshot of the integrated water vapour flux at 14:00 UTC for the 21 October 2008 case and at 08:00 UTC for the 26 December 2008 case.

Bresson et al. (2009) and Boudevillain et al. (2009) in which this westwards shift is explained as the effect of the Alps deflection. Figures 7 and 8 also show that among these events, those with precipitating systems located in the Vivarais region (northeastern part of the $\mathrm{CV}$ region) have a more southwesterly feeding flow as for the 12 August 2008 and 3 September 2008 events. The others with precipitating systems located over the Cévennes region (southwestern part of the CV) are fed by a southerly low-level flow. These feeding flows are most of the time driven either by a local pressure low situated over the Spanish Catalonia or by a large upper-level trough extending over Western France and Spain (not shown). This is consistent with the statistical results of Jansà et al. (2001). Moisture is brought within 5 to $7 \mathrm{~h}$ from offshore Spanish Catalonia $\left(41^{\circ} \mathrm{N}\right)$ to the French Mediterranean coast. This time lag may reach up to $9 \mathrm{~h}$ with a weaker low-level flow as in the 20 October 2008 event. Moisture then takes part in the precipitating systems within the next one or two hours.

Both Southern Alps events are fed with a southsouthwesterly low-level flow veering south to southeasterly when approaching the coast. This low-level flow is driven by a low pressure area extending from Southwestern France to the Balearic Islands and converges near the coast with an easterly flow coming from the Gulf of Genoa. This easterly flow is either moist and contributes to the feeding of the precipitating system (22 October 2009 case) or is drier (18 September 2009 case) and only enhances the local convergence. Moisture is brought in about $6 \mathrm{~h}$ from $41^{\circ} \mathrm{N}$ 

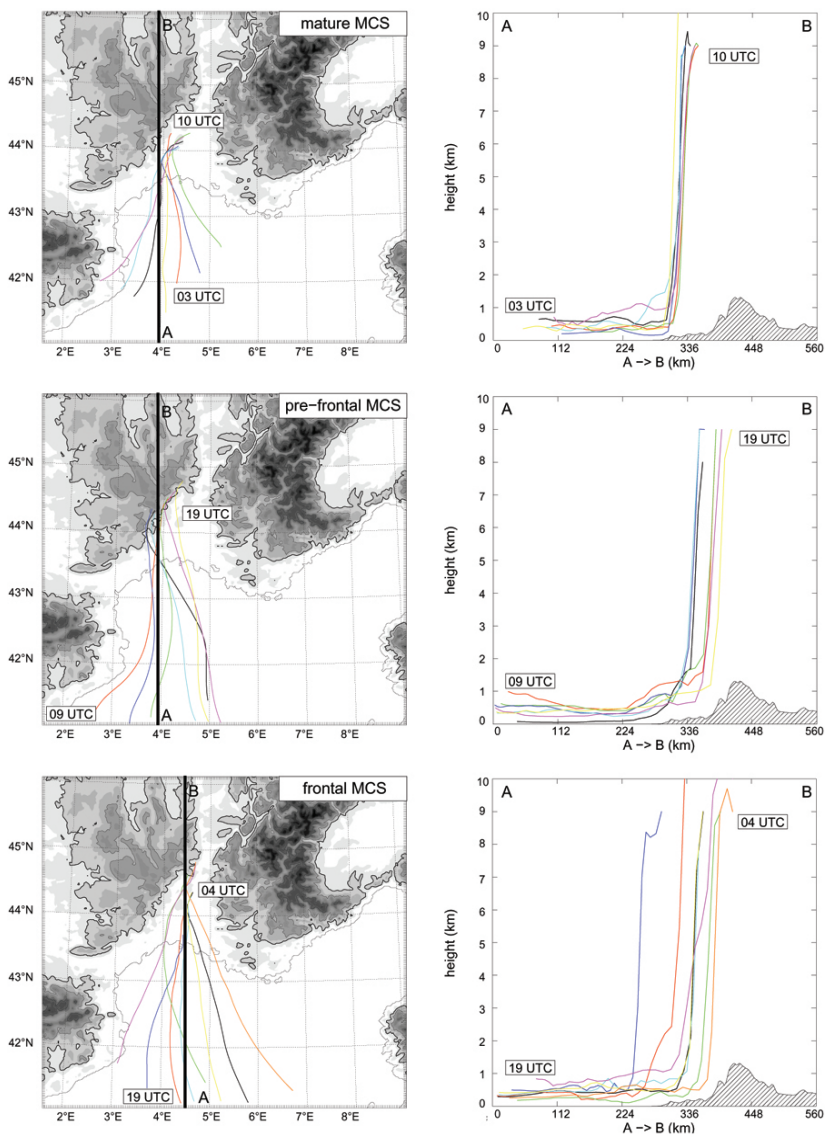

Fig. 12. Backward trajectories of some air parcels taken of the 21 October 2008 precipitating systems simulated by HRA2.5 in three different phases of the event - mature convection well ahead of the front (top), pre-frontal convection (middle) and convection embedded in a frontal disturbance (bottom). The backward trajectories are projected both on an horizontal plane (left panels) and on a vertical cross-section (right panels). The vertical crosssection follows the line $\mathrm{AB}$ displayed on the left planels. The orography is superimposed in grey scale as in Fig. 2 for the left panels and as a hatched area for the right panels.

and from the Gulf of Genoa to the French Mediterranean coast and then enters the precipitating systems within the next hour. The Roussillon event is fed by an easterly flow coming from the Gulf of Genoa and the Northern Tyrrhenian Sea. This large-scale flow driven by a dynamic low situated between the Balearic Islands and Corsica brings moisture in 10 to $12 \mathrm{~h}$ from Corsica and offshore Italy to the Roussillon coast. Here again, our results on SA and R cases are consistent with Ricard et al. (2010) and Boudevillain et al. (2009) even if the feeding flow of our Roussillon event is more easterly.

\section{Origin of the moisture involved in HPEs}

In order to feature its remote origin, the moist feeding flow studied in the previous section is identified in the RAI simulations and analysed as described in Sect. 2.2. Figures 13-16 show the backward trajectories of some air parcels taken in the moist low-level inflow feeding the precipitating systems for all the studied cases. The 4-day backward trajectories of the 21 October 2008, 1 November 2008, 26 December 2008, 20 and 22 October 2009 cases go beyond the boundaries of the RAI10 domain. As a consequence, for all these cases except the 26 December 2008 one, the backward trajectories were performed with the RAI40 simulations. As long as they remain within the RAI10 domain, the backward trajectories computed with RAI40 and RAI10 coincide. For the 26 December 2008 case, the backward trajectories were computed with the RAI10 simulation because the northern boundary of the RAI40 domain is very close to the one of the RAI10 domain. For every other case, the backward trajectories were performed with RAI10. The evolution of the parcel water vapour mixing ratio along the trajectories is summarised in Table 2. It gives, for all the cases, the approximate water vapour mixing ratio of the low-level moist flow entering the precipitating systems, just before being lifted up (Final WV mixing ratio), the amount of moisture initially contained in the air mass at the beginning of the 4-day backward trajectories (Initial WV mixing ratio) and the amount of moisture gained by the low-level flow when it circulates in the lowest $1000 \mathrm{~m}$ above the Mediterranean Sea (WV mixing ratio gained from the sea). The time span the air parcels spend in these marine low-levels is also given in Table 2. The amount of moisture gained along the part of the pathways above $1000 \mathrm{~m}$ is not displayed in the table. Except for the 18 September 2009 event, this latter contribution represents about $10 \%$ to $20 \%$ of the total water vapour mixing ratio of the moist feeding flow entering the precipitating systems (less than $2 \mathrm{~g} \mathrm{~kg}^{-1}$ ). This moisture is mainly gained by mixing with the environment during ascents and descents. In the 18 September 2009 event, this contribution is larger because a quite large amount of moisture $\left(3.5 \mathrm{~g} \mathrm{~kg}^{-1}\right)$ is gained around Gibraltar when the air parcels descend from $1500 \mathrm{~m}$ to $1000 \mathrm{~m}$. This moisture is likely associated to local evaporation.

It appears from Figs. 13-16 that the air masses contributing to the moist feeding flow remain in the lower half of the troposphere all along their 4-day trajectories. They are most of the time situated between $1000 \mathrm{~m}$ and $3000 \mathrm{~m}$ before descending in the low-levels above the Mediterranean in the last 2 days before the HPE triggering (cf. Table 2). For all CV and SA cases - all convective cases - the tracks of moisture transport the last day before the HPE triggering stretch northwards in the low-levels over the Western Mediterranean basin following two main branches. The first branch advances north-northeastwards along the Spanish coast and over the Balearic Islands on the west of 
Table 2. Approximate water vapour mixing ratios of the parcels along their pathway.

\begin{tabular}{|c|c|c|c|c|}
\hline Case & $\begin{array}{l}\text { Final WV } \\
\text { mixing ratio }\end{array}$ & $\begin{array}{l}\text { Initial WV } \\
\text { mixing ratio }\end{array}$ & $\begin{array}{l}\text { WV mixing ratio } \\
\text { gained from the sea }\end{array}$ & $\begin{array}{l}\text { Time in the lowest } \\
1000 \mathrm{~m} \text { above the sea }\end{array}$ \\
\hline 12 Aug 2008 & $15 \mathrm{~g} \mathrm{~kg}^{-1}$ & $2.5 \mathrm{~g} \mathrm{~kg}^{-1}$ & $10 \mathrm{~g} \mathrm{~kg}^{-1}$ & $36-60 \mathrm{~h}$ \\
\hline 3 Sep 2008 & $13.5 \mathrm{~g} \mathrm{~kg}^{-1}$ & $4 \mathrm{~g} \mathrm{~kg}^{-1}$ & $8 \mathrm{~g} \mathrm{~kg}^{-1}$ & $24 \mathrm{~h}$ \\
\hline 20 Oct 2008 & $10 \mathrm{~g} \mathrm{~kg}^{-1}$ & $3.5 \mathrm{~g} \mathrm{~kg}^{-1}$ & $6.5 \mathrm{~g} \mathrm{~kg}^{-1}$ & $24 \mathrm{~h}$ and more \\
\hline 21 Oct 2008 & $12 \mathrm{~g} \mathrm{~kg}^{-1}$ & $3-6 \mathrm{~g} \mathrm{~kg}^{-1}$ & $7-4 \mathrm{~g} \mathrm{~kg}^{-1}$ & $24 \mathrm{~h}$ and more \\
\hline 1 Nov 2008 & $9 \mathrm{~g} \mathrm{~kg}^{-1}$ & $4 \mathrm{~g} \mathrm{~kg}^{-1}$ & $4 \mathrm{~g} \mathrm{~kg}^{-1}$ & $12 \mathrm{~h}$ \\
\hline 8 Oct 2009 & $11 \mathrm{~g} \mathrm{~kg}^{-1}$ & $5.5 \mathrm{~g} \mathrm{~kg}^{-1}$ & $5.5 \mathrm{~g} \mathrm{~kg}^{-1}$ & $24 \mathrm{~h}$ and more \\
\hline 20 Oct 2009 & $10 \mathrm{~g} \mathrm{~kg}^{-1}$ & $4.5 \mathrm{~g} \mathrm{~kg}^{-1}$ & $3.5 \mathrm{~g} \mathrm{~kg}^{-1}$ & $12-24 \mathrm{~h}$ \\
\hline 18 Sep 2009 & $11 \mathrm{~g} \mathrm{~kg}^{-1}$ & $3 \mathrm{~g} \mathrm{~kg}^{-1}$ & $3 \mathrm{~g} \mathrm{~kg}^{-1}$ & $18-24 \mathrm{~h}$ \\
\hline 22 Oct 2009 & $9 \mathrm{~g} \mathrm{~kg}^{-1}$ & $3.5 \mathrm{~g} \mathrm{~kg}^{-1}$ & $3.5 \mathrm{~g} \mathrm{~kg}^{-1}$ & $18-24 \mathrm{~h}$ \\
\hline 26 Dec 2008 & $3.5 \mathrm{~g} \mathrm{~kg}^{-1}$ & $2 \mathrm{~g} \mathrm{~kg}^{-1}$ & $0.7 \mathrm{~g} \mathrm{~kg}^{-1}$ & $0-15 \mathrm{~h}$ \\
\hline
\end{tabular}
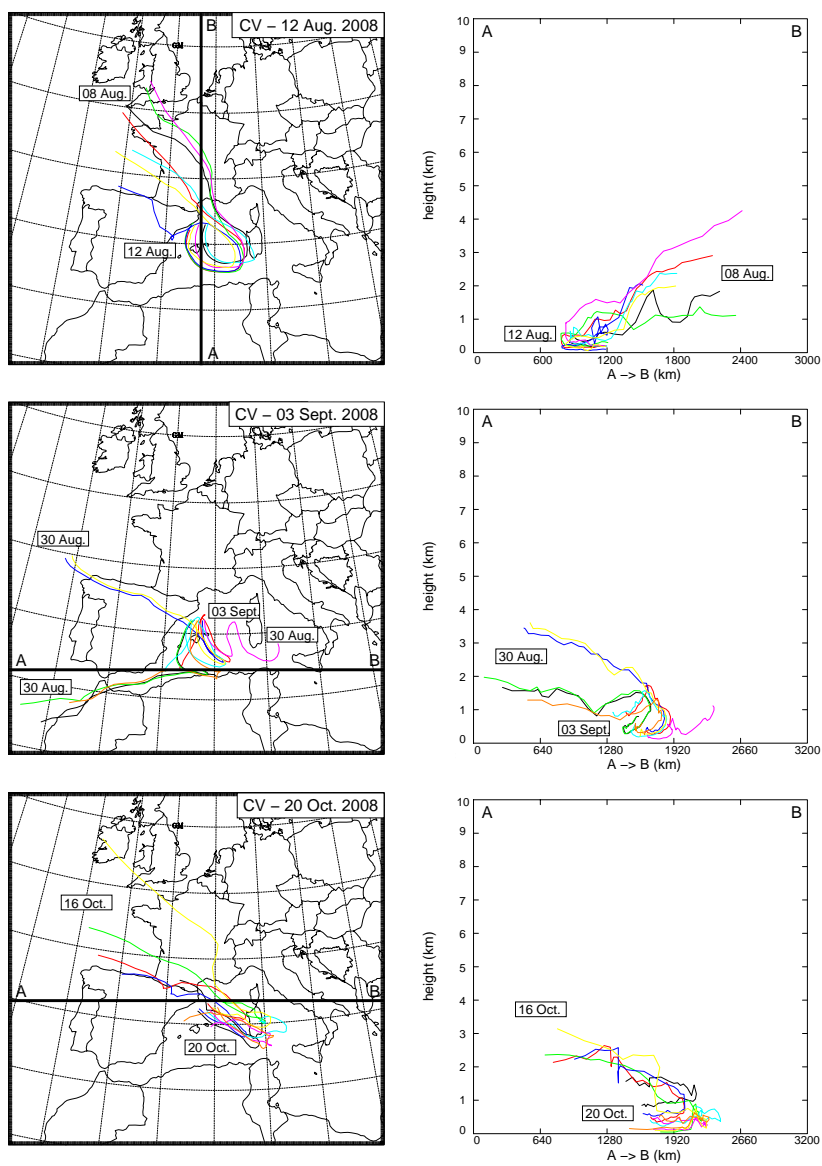

Fig. 13. Backward trajectories of some air parcels taken in the moist feeding flow obtained with the RAI10 simulation for three CV cases: the 12 August 2008 (top), the 3 September 2008 (middle) and the 20 October 2008 (bottom). The backward trajectories are projected both on an horizontal plane (left panels) and on a vertical cross-section (right panels). The vertical cross-section follows the line $\mathrm{AB}$ displayed on the left planels.
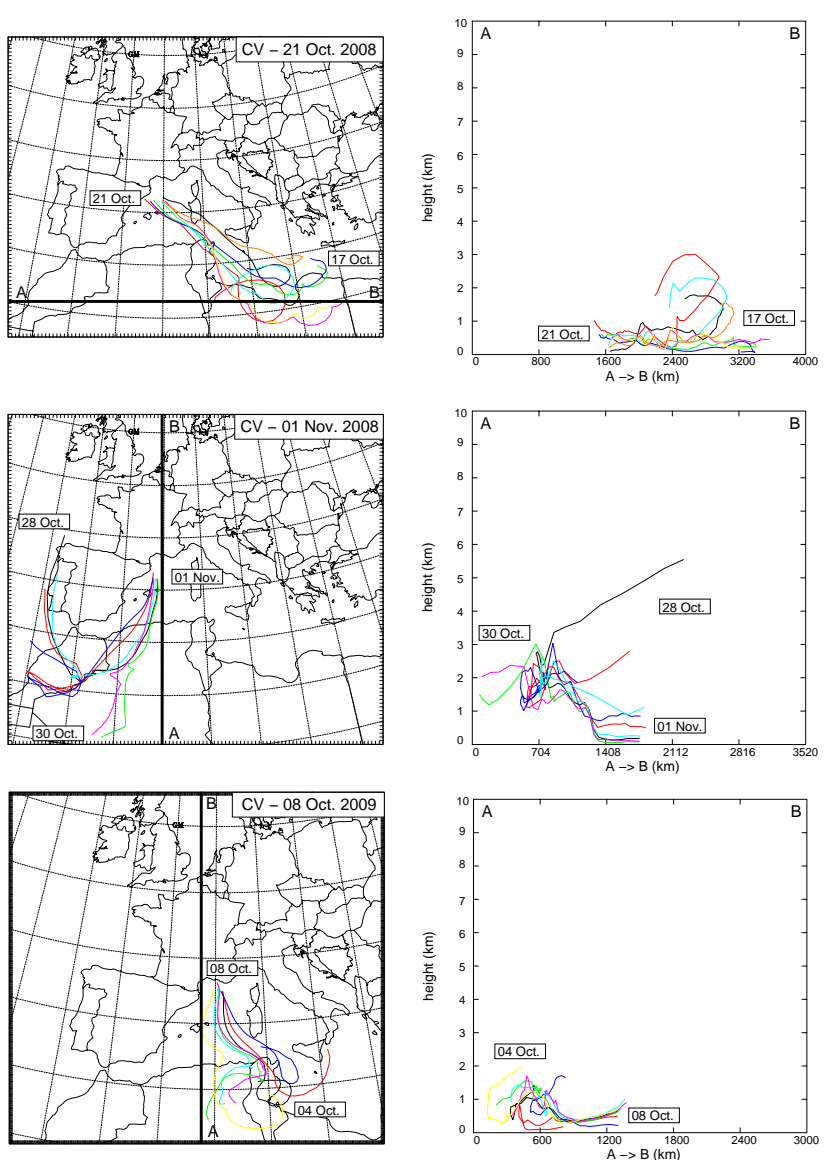

Fig. 14. Same as Fig. 13, but for three other CV cases: the 21 October 2008 (top), the 1 November 2008 (middle) and the 8 October 2009 (bottom). The backward trajectories of the 21 October 2008 and 1 November 2008 cases are performed with the RAI40 simulation. 

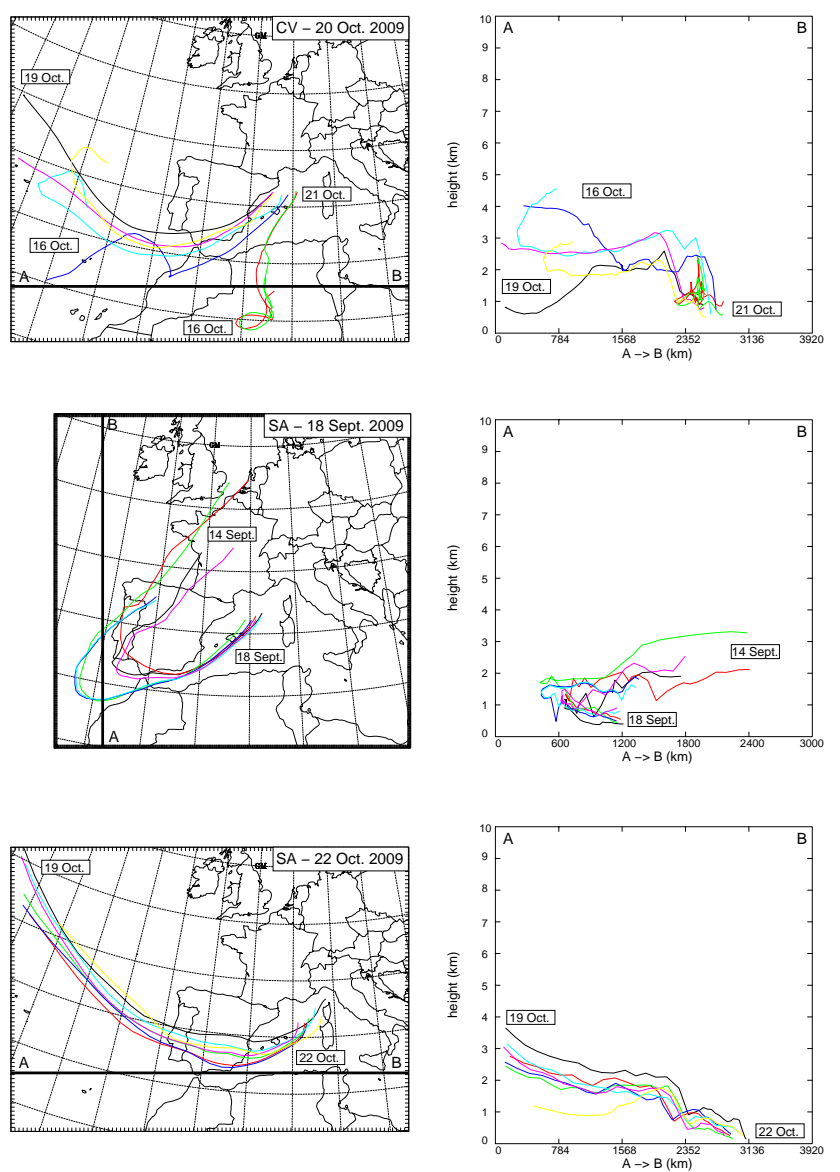

Fig. 15. Same as Fig. 13, but for the last CV case, the 20 October 2009 (top), and both SA cases, the 18 September 2009 (middle) and the 22 October 2009 (bottom). The backward trajectories of the 20 October 2009 and 22 October 2009 cases are performed with the RAI40 simulation.

the basin while the second one extends north-northwestwards from Tunisia along Sardinia. During this transport phase, moisture is gained from the Mediterranean Sea.

Figures 13-16 and Table 2 also show that the 4-day tracks of the moisture transport and the amount of moisture gained from the Mediterranean vary from one event to another according to the synoptic pattern and its evolution. In the first four cases - the 12 August 2008, the 3 September 2008, the 20 October 2008 and the 21 October 2008 - and in the 8 October 2009 one, the parcel pathways remain at least $24 \mathrm{~h}$ and sometimes up to more than 4 days in the low-levels above the Mediterranean Sea. During this quite long time, large amounts of moisture are gained from the Mediterranean $-6.5-10 \mathrm{~g} \mathrm{~kg}^{-1}$ for the first four cases and $5.5 \mathrm{~g} \mathrm{~kg}^{-1}$ and $4 \mathrm{~g} \mathrm{~kg}^{-1}$ respectively for the 8 October 2009 case and at the end of the 21 October 2008 one. This is allowed by the weak anticyclonic conditions with occasionally local and transient pressure lows which prevail above the Western Mediterranean Sea in the last 3 or 4 days before these
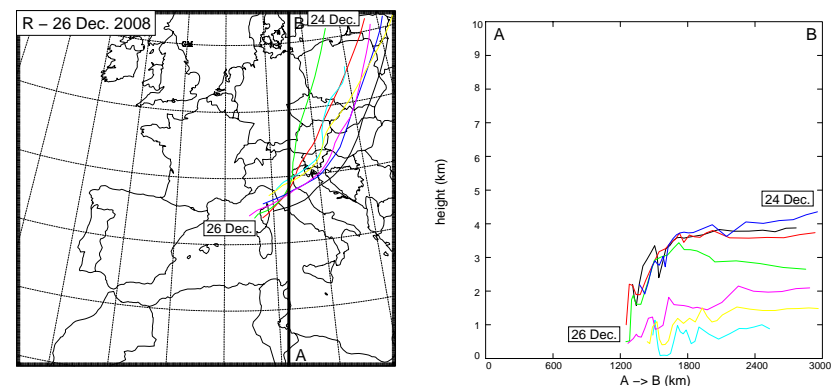

Fig. 16. Same as Fig. 13, but for the 26 December 2008 Roussillon case.

events. These anticyclonic conditions confine moisture in the low-levels above the sea and force subsidence of the air parcels towards these moist low-levels. The anticyclonic flow perturbated by local transient pressure lows makes the air parcels move slowly in these moist low-levels following roundabout pathways. Such moisture recharging mechanism was qualitatively discussed long ago by Jansà (1959), and partially quantified by Ramis (1995) based on a radiosounding climatology. The amounts of moisture gained from the Mediterranean Sea are lower for the 8 October 2009 case and at the end of the 21 October 2008 one. In these two cases, the amounts of moisture transported over 4 days from remote regions towards the Western Mediterranean Sea are larger - respectively $5.5 \mathrm{~g} \mathrm{~kg}^{-1}$ and $6 \mathrm{~g} \mathrm{~kg}^{-1}$ instead of $2.5 \mathrm{~g} \mathrm{~kg}^{-1}$ to $4 \mathrm{~g} / \mathrm{kg}$ for the first four cases. The air parcels are thus moister when arriving above the Mediterranean Sea and less moisture can be gained from the sea before saturation is reached. The large amounts of moisture provided by remote sources for these two cases appear related to a high humidity area over tropical Africa in the ERA-Interim analysis (not shown). The backward trajectories 3 or 4 days before the events indiciate different origins and pathways for these 5 cases. For the 12 August 2008, 3 September 2008 and 20 October 2008 cases, trajectories pass over France or Northern Spain transporting air masses from Northern Atlantic Ocean. Transports of African and Eastern Mediterranean air masses are identified for the 21 October 2008 and 8 October 2009 cases, and of Atlantic offshore Morocco air masses for the 3 September 2008 case.

Anticyclonic conditions also prevail over the Mediterranean Sea from 5 days till one day before the 26 December 2008 event. A large pressure high drives over Central Europe and towards the Northwestern Mediterranean Sea an air mass coming from a decaying depression over the Baltic Sea. However, in this case, the air mass is much colder so that very little moisture can be added to the $2 \mathrm{~g} \mathrm{~kg}^{-1}$ coming from the decaying depression before saturation is reached. Besides, over the Northwestern Mediterranean Sea, the air mass is driven by a cyclonic flow much more dynamic than in the five previous cases. All this contributes in limiting the amount of moisture gained from the Mediterranean Sea. 


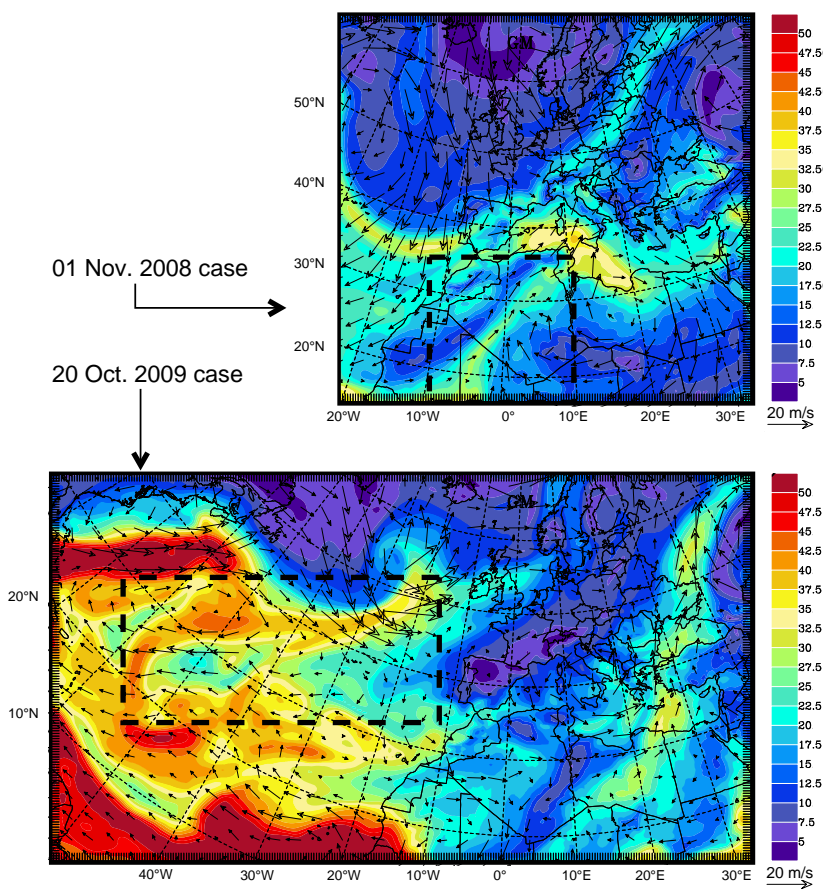

Fig. 17. ERA-Interim water vapour thickness (in mm, colour scale on the right of each panel) at 00:00 UTC, 28 October 2008 (top) and at 00:00 UTC, 19 October 2009 (bottom) together with ERAInterim 1.25-km a.s.l. (top) and 2-km a.s.l. (bottom) horizontal wind vectors. Wind arrows are drawn every 6 grid points with a scale in $\mathrm{m} / \mathrm{s}$ given by the length of the arrow at the bottom right of each panel. The top black dashed rectangle stresses the transport of African tropical moisture and the bottom one, the transport of Atlantic tropical humidity.

For every other case, cyclonic conditions with stronger dynamic forcing prevail over the Western Mediterranean in the last 4 or 3 days before the events. In all these cases, the trajectories descend to the low-levels above the Mediterranean Sea less than $24 \mathrm{~h}$ before the HPE triggering. The subsidence is most of the time due to the Foehn or downslope moist flows that develop downstream the mountain ranges surrounding the Western Mediterranean Sea (e.g. Foehn downstream the Atlas for the 1 November 2008 case, or descending moist flow on the lee side of the Eastern Spanish mountains for the 22 October 2009). The amounts of moisture gained from the Mediterranean are here remarkably lower $\left(3-4 \mathrm{~g} \mathrm{~kg}^{-1}\right)$. For these 4 cases, the part of moisture coming from remote regions $\left(3-4.5 \mathrm{~g} \mathrm{~kg}^{-1}\right)$ is slightly larger than the local moisture one. In particular quite large amounts of moisture are provided by remote sources for the 1 November 2008 and 20 October 2009 cases. They appear in the ERA-Interim reanalyses to be related respectively to African tropical humidity and Atlantic tropical moisture (Fig. 17). For all these cases, the tracks of moisture transport pass over Northern Africa, Gibraltar and Spain bringing Atlantic (18 September 2009, 20 October 2009 and 22 October 2009 cases) and African (1 November
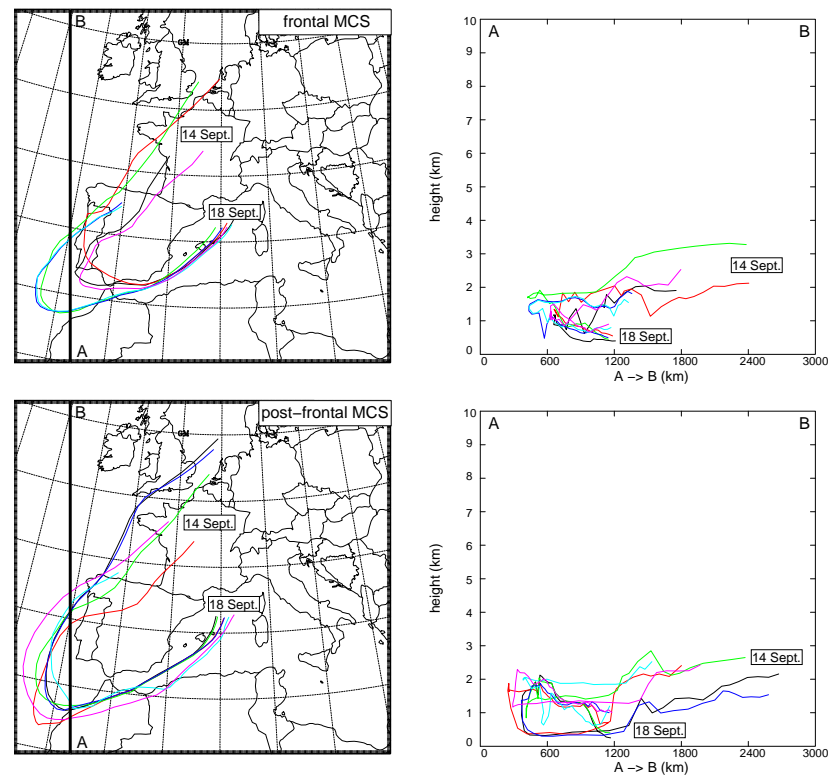

Fig. 18. Backward trajectories of some air parcels taken in the moist low-level flow feeding the 18 September 2009 precipitating systems obtained with the RAI10 simulation in two different phases of the event - convection embedded in a frontal disturbance (top) and postfrontal mature convection (bottom). The backward trajectories are projected both on an horizontal plane (left panels) and on a vertical cross-section (right panels). The vertical cross-section follows the line $\mathrm{AB}$ displayed on the left panels.

2008 case) air masses towards the Western Mediterranean Sea where they then follow the western low-level transport branch.

Here again, the origin of the air masses composing the moist low-level feeding flow does not change a lot during an event. The backward trajectories of air parcels taken in the moist flow feeding the precipitating systems in different phases of an event remain most of the time very similar (e.g. for the 18 September 2009 case shown in Fig. 18). The main evolution observed during an event is a slight shift of both the origin of the parcels and their tracks towards the French Mediterranean coast. This is what happens e.g. in the 20 October 2008 event during which the origin of the parcels evolves from the English Channel to the Bay of Biscay and their track over the Mediterranean moves slightly southwards (not shown), or in the 21 October 2008 and 1 November 2008 cases during which both the origin of the parcels and their track shift respectively westwards (see Fig. 19) and eastwards (not shown). These slight shifts may correspond to a modification of the respective contribution magnitude of the different air masses forming the moist feeding flow. In our HPE set, such a modification is substantial only in the 21 October 2008 case. During this event, the contribution of African moisture to the feeding flow becomes larger $6 \mathrm{~g} \mathrm{~kg}^{-1}$ in the frontal phase against $3 \mathrm{~g} \mathrm{~kg}^{-1}$ in the prefrontal one (see Table 2) - as the backward trajectories shift westwards. 

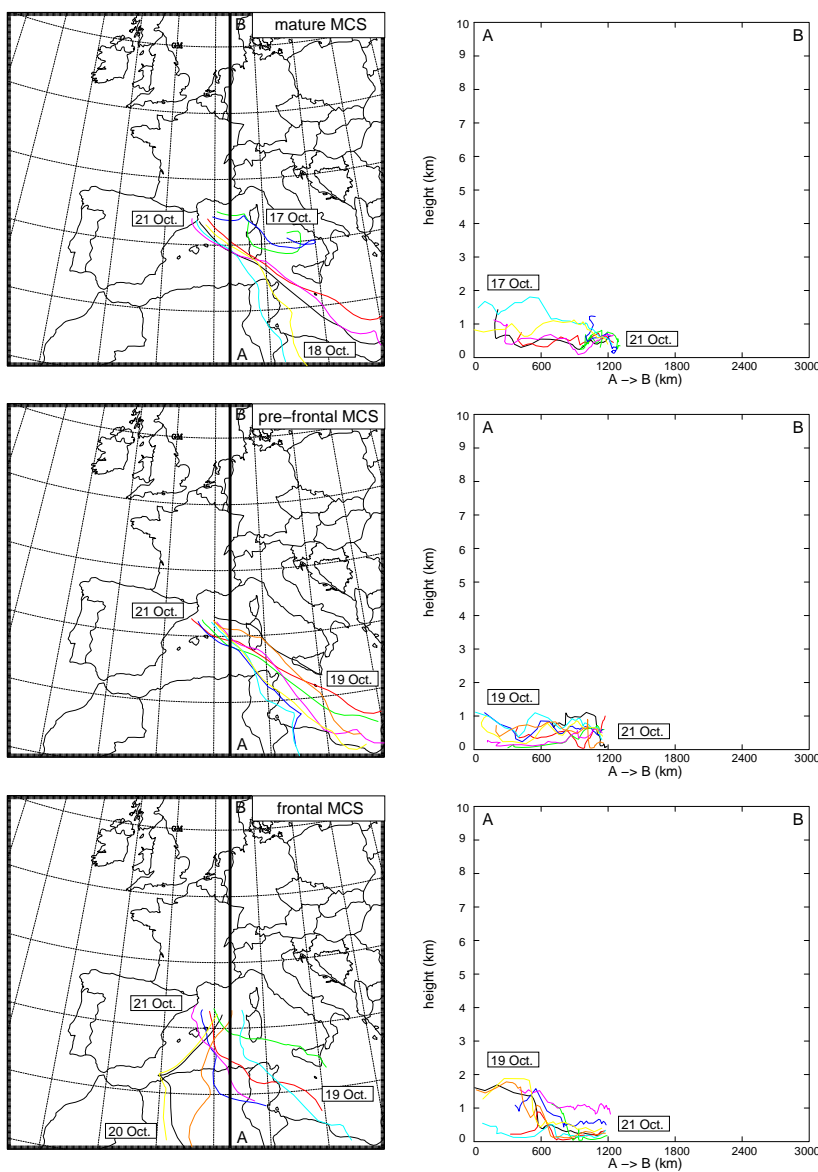

Fig. 19. Same as Fig. 18 for the feeding of three different phases of the 21 October 2008 event - mature convection well ahead of the front (top), pre-frontal convection (middle) and convection embedded in a frontal disturbance (bottom).

To sum up, the moisture of the flow feeding the heavy precipitating systems is mainly provided by evaporation of the Mediterranean Sea in the last 2 days before the HPE triggering and by the transport of moisture from remote sources over more than 3-4 days. The Mediterranean Sea is the main moisture source $(>50 \%)$ when anticyclonic conditions prevail during the days before the HPE triggering. It moistens the low-levels and brings the low-level feeding flow near saturation. When more moisture is provided by remote sources, saturation is reached more rapidly and the contribution of the Mediterranean Sea is reduced. On the contrary, when cyclonic conditions prevail the days before the HPE, less moisture is gained from the Mediterranean Sea and a combination of remote and local moisture is then needed to approach saturation. Most of the time (all cases except 21 October 2008, 1 November 2008 and 8 October 2009 cases), remote moisture comes from the Atlantic Ocean region. However, the contribution of this remote source is not very large $\left(2-4.5 \mathrm{~g} \mathrm{~kg}^{-1}\right)$. African tropical moisture is another less frequent ( 3 cases out of 10 ) but larger $\left(4-6 \mathrm{~g} \mathrm{~kg}^{-1}\right)$ remote source. These results are in good agreement with those of Turato et al. (2004) for the Piemont 2000 event. The studies agree about both the relative contribution of the various moisture sources and the moisture transport time-scale and pathways. Turato et al. (2004) found a contribution of the Mediterranean Sea of 20\% which is quite low but consistent with our results as the Piedmont 2000 event occurred after some days of cyclonic conditions over the Western Mediterranean Sea. The Atlantic Ocean contribution of $60 \%$ is quite high in comparison with our study but the difference is explained by the role of the the tropical storm Leslie and its extratropical transition in the Piedmont 2000 event. In our studied cases, no extratropical remnants of tropical systems contribute to the HPE moisture supply. It seems that such a contribution is rather occasional and not really decisive (it provides only about $15 \%$ of the Piedmont 2000 moisture supply according to Turato et al., 2004).

\section{Conclusions}

The ten Heavy Precipitating Events that occurred over the French Mediterranean region during the autumns of 2008 and 2009 have been investigated to determine the origin of their moisture supply and the tracks of long-range moisture transport. High-resolution numerical simulations ( $2.5 \mathrm{~km}$ horizontal resolution) of these ten cases performed with the French non-hydrostatic research model Meso-NH allowed us to characterise the moisture inflow feeding the heavy precipitating systems using on-line eulerian passive tracers. Larger-scale simulations $(40 \mathrm{~km}$ and $10 \mathrm{~km}$ horizontal resolution) then allowed us to analyse the moisture transport over a 4-day long period and to identify the remote origin of this moisture inflow.

The moisture inflow entering the heavy precipitating systems of all convective events was found to be confined within a thin $1000 \mathrm{~m}$ deep layer above the Mediterranean Sea. The vertical extent of the inflow appeared to be related with the depth of the conditionally unstable boundary layer. For the non-convective HPE, the precipitating system was found embedded in a large-scale moist disturbance and fed by the lowest $3000 \mathrm{~m}$ of this disturbed air mass. For all the studied cases, the low-level feeding inflow crosses the most northwestern part of the Mediterranean basin in 5 to $10 \mathrm{~h}$. CV events are fed with a southerly low-level flow veering slightly westwards when approaching the French Mediterranean coast. SA events are fed by a south-southwesterly low-level flow veering south to southeasterly and converging with an easterly flow from the Gulf of Genoa when approaching the coast. The $\mathrm{R}$ event feeding flow is oriented easterly, driven by a dynamic low situated between the Balearic Islands and Corsica. These moist feeding inflows remain almost unchanged all along the events. 
The moisture feeding the heavy precipitating systems is both provided by evaporation of the Mediterranean Sea within the last 2 days before the HPE triggering and transported from remote sources over more than 4 days. Evaporation of the Mediterranean Sea is the main moisture source $\left(6.5 \mathrm{~g} \mathrm{~kg}^{-1}\right.$ to $10 \mathrm{~g} \mathrm{~kg}^{-1}$ out of $10 \mathrm{~g} \mathrm{~kg}^{-1}$ to $\left.15 \mathrm{~g} \mathrm{~kg}^{-1}\right)$ when anticyclonic conditions prevail during the last 3 or 4 days before the HPE. Large amounts of moisture can nevertheless also be provided by remote sources (about $6 \mathrm{~g} \mathrm{~kg}^{-1}$ ). In this case, the contribution of the Mediterranean Sea is reduced as the feeding flow reaches saturation more rapidly. When cyclonic conditions prevail before the HPE, less moisture is gained from the Mediterranean Sea $\left(3 \mathrm{~g} \mathrm{~kg}^{-1}\right.$ to $4 \mathrm{~g} \mathrm{~kg}^{-1}$ ). The relative contribution of local and remote sources is then more balanced.

Most of the time, remote moisture comes from extratropical evaporation and/or tropical humidity transport over the Atlantic Ocean. The contribution of this remote source is however not very large (about $4 \mathrm{~g} \mathrm{~kg}^{-1}$ ). African tropical moisture is a less frequent ( 3 cases out of 10) but larger $\left(4 \mathrm{~g} \mathrm{~kg}^{-1}\right.$ to $\left.6 \mathrm{~g} \mathrm{~kg}^{-1}\right)$ remote source. Moisture is transported from these remote sources towards the Western Mediterranean Sea in the lower half of the troposphere and most of the time between $1000 \mathrm{~m}$ and $3000 \mathrm{~m}$. The remote moisture pathways descend in the low-levels above the Mediterranean Sea following either Foehn, or downslope moist flows on the lee side of the mountain ranges around the Mediterranean Sea, or large-scale anticyclonic subsidences. Local Mediterranean moisture is then gained along the lowlevel pathways towards the Northwestern Mediterranean basin following two main branches along the Spanish coast and west to Sardinia.

In this study, the contribution of the different local and remote moisture sources is inferred from the water vapour mixing ratio evolution along some air parcel trajectories. This has allowed to determine the origins and pathways of moisture and provide a first rough estimation of the respective contribution of the different moisture sources. A further work is currently in progress in order to confirm the results of the present study with a more quantitative estimation obtained through water vapour budgets. This study also contributes to the pre-studies carried out for preparing the future field campaign HyMeX (Hydrological Cycle in the Mediterranean Experiment, http://www.hymex. org/) dedicated to the study of HPEs in the Mediterranean region. It helps to design the deployment of research instruments for documenting the HPE feeding inflow.

Acknowledgements. This work has been carried out in the framework of the VAPIMED project, sponsored by the CNRS/INSU/LEFE research program. The authors thank the Meso-NH support team for its help in using the Meso-NH model.

Edited by: A. Mugnai

Reviewed by: two anonymous referees

\section{References}

Belamari, S.: Report on uncertainty estimates of an optimal bulk formulation for surface turbulent fluxes, MERSEA IP Deliverable, D.4.1.2, 29, 2005.

Bluestein, H. B. and Jain, M. H.: Formation of mesoscale lines of precipitations: Severe squall lines in Oklahoma during the spring, J. Atmos. Sci., 42(16), 1711-1732, 1985.

Boudevillain, B., Argence, S., Claud, C., Ducrocq, V., Joly, B., Joly, A., Lambert, D., Nuissier, O., Plu, M., Ricard, D., Arbogast, P., Berne, A., Chaboureau, J.-P., Chapon, B., Crépin, F., Delrieu, G., Doerflinger, E., Funatsu, B. M., Kirstetter, P.E., Masson, F., Maynard, K., Richard, E., Sanchez, E., Terray, L., and Walpersdorf, A.: Cyclogénèses et précipitations intenses en région méditerranéenne : origines et caractéristiques, La Météorologie 8 ème série, 66, 18-28, 2009 (in French).

Bougeault, P. and Lacarrère, P.: Parameterization of orographyinduced turbulence in a meso-beta-scale model, Mon. Weather Rev., 117(8), 1872-1890, 1989.

Bresson, R., Ricard, D., and Ducrocq, V.: Idealized mesoscale numerical study of Mediterranean heavy precipitating convective systems, Meteorol. Atmos. Phys., 103, 45-55, doi:10.1007/ s00703-008-0338-z, 2009.

Buzzi, A., Tartaglione, N., and Malguzzi, P.: Numerical simulations of the 1994 Piedmont flood: role of orography and moist processes, Mon. Weather Rev., 126(9), 2369-2383, 1998.

Caniaux, G., Redelsperger, J.-L., and Lafore, J.-P.: A numerical study of the stratiform region of a fast-moving squall line, J. Atmos. Sci., 51(14), 2046-2074, 1994.

Cuxart, J., Bougeault, P., and Redelsperger, J.-L.: A turbulence scheme allowing for mesoscale and large-eddy simulations, Q. J. Roy. Meteor. Soc., 126(562), 1-30, doi:10.1002/qj. 49712656202, 2000.

Delrieu, G., Ducrocq, V., Gaume, E., Nicol, J., Payrastre, O., Yates, E., Kirstetter, P.-E., Andrieu, H., Ayral, P.-A., Bouvier, C., Creutin, J.-D., Livet, M., Anquetin, S., Lang, M., Neppel, L., Obled, C., Parent-du-Châtelet, J., Saulnier, G.-M., Walpersdorf, A., and Wobrock, W.: The catastrophic flash-flood event of 89 septembre 2002 in the Gard region, France: A first casestudy for the Mediterranean Hydrometeorological Observatory, J. Hydrometeorol., 6(1), 34-52, 2005.

Ducrocq, V., Aullo, G., and Santurette, P.: Les pécipitations intenses et les inondations des 12 et 13 novembre 1999 sur le sud de la France, La Météorologie 8 ème série, 42, 18-23, 2003 (in French).

Ducrocq, V., Lebeaupin, C., Thouvenin, T., and Giordani, H.: L'évènement des 8-9 septembre 2002: Situation météorologique et simulation à méso-échelle, La Houille Blanche, 6, 86-92, 2004 (in French).

Ducrocq, V., Bouttier, F., Malardel, S., Montmerle, T., and Seity, Y.: Le projet AROME, La Houille Blanche, 2005-2, 39-43, 2005 (in French).

Ducrocq, V., Nuissier, O., and Ricard, D.: A numerical study of three catastrophic precipitating events over southern France. Part II: Mesoscale trigerring and stationarity factors, Q. J. Roy. Meteor. Soc., 134(630), 131-145, doi:10.1002/qj.199, 2008.

Gal-Chen, T. and Somerville, R. C. J.: On the use of a coordinate transformation for the solution of the Navier-Stokes equations, J. Comput. Phys., 17, 209-228, 1975. 
Gheusi, F. and Stein, J.: Lagrangian description of airflows using eulerian passive tracers, Q. J. Roy. Meteor. Soc., 128(579), 337360, doi:10.1256/00359000260498914, 2002.

Homar, V., Ramis, C., Romero, R., Alonso, S., García-Moya, J. A., and Alarcón, M.: A case of convection development over the Western Mediterranean Sea: A study through numerical simulations, Meteorol. Atmos. Phys., 71, 169-188, 1999.

Homar, V., Romero, R., Ramis, C., and Alonso, S.: Numerical study of the October 2000 torrential precipitation event over eastern Spain: analysis of the synoptic-scale stationarity, Ann. Geophys., 20(12), 2047-2066, 2002.

Jansà, A., Genoves, A., Picornell, M. A., Campins, J., Riosalido, R., and Carretero, O.: Western Mediterranean cyclones and heavy rain. Part 2: Statistical approach, Meteorol. Appl., 8(1), 43-56, doi:10.1017/S1350482701001049, 2001.

Jansà, J. M.: La masa de aire Mediterránea, Rev. de Geofisíca, 69, 35-50, 1959 (in Spanish).

Kain, J.-S. and Fritsch, J.-M.: Convective parameterization for mesoscale models: the Kain-Fritsch scheme, Meteor. Mon., 46, 165-170, 1993.

Krichak, S. O. and Alpert, P.: Role of large scale moist dynamics in November 1-5, 1994, hazardous Mediterranean weather, J. Geophys. Res., 103(D16), 19453-19468, 1998.

Lafore, J.-P., Stein, J., Asencio, N., Bougeault, P., Ducrocq, V., Duron, J., Fischer, C., Héreil, P., Mascart, P., Masson, V., Pinty, J.-P., Redelsperger, J.-L., Richard, E., and Vilà-Guerau de Arellano, J.: The Meso-NH Atmospheric Simulation System. Part I: Adiabatic formulation and control simulations, Ann. Geophys., 16(1), 90-109, 1998.

Massacand, A. C., Wernli, H., and Davies, H. C.: Heavy precipitation on the Alpine southside: An upper-level precursor, Geophys. Res. Lett., 25, 1435-1438, 1998.

Masson, V.: A physically based scheme for the urban energy budget in atmospheric models, Bound.-Lay. Meteorol., 94(3), 357-397, doi:10.1023/A:1002463829265, 2000.

Mlawer, E. J., Taubman, S. J., Brown, P. D., Iacono, M. J., and Clough, S. A.: Radiative transfer for inhomogeneous atmospheres: RRTM, a validated correlated-k model for the longwave, J. Geophys. Res., 102(D14), 16663-16682, 1997.

Noilhan, J. and Mahfouf, J.-F.: The ISBA land surface parameterisation scheme, Global Planet. Change, 13, 145-159, doi:10.1016/0921-8181(95)00043-7, 1996.

Nuissier, O., Ducrocq, V., and Ricard, D.: A numerical study of three catastrophic precipitating events over southern France. Part I: Numerical framework and synoptic ingredients, Q. J. Roy. Meteor. Soc., 134(630), 111-130, doi:10.1002/qj.200, 2008.

Peñarrocha, D., Estrela, M. J., and Millán, M.: Classification of daily rainfall patterns in a Mediterranean area with extreme intensity levels: the Valencia region, Int. J. Climatol., 22, 677695, doi:10.1002/joc.747, 2002.

Pergaud, J., Masson, V., Malardel, S., and Couvreux, F.: A parameterization of dry thermals and shallow cumuli for mesoscale numerical weather prediction, Bound.-Lay. Meteorol., 132(1), 83-106, doi:10.1007/s10546-009-9388-0, 2009.

Pinty, J.-P. and Jabouille, P.: A mixed-phased cloud parametrization for use in a mesoscale non-hydrostatic model: Simulations of a squall line and of orographic precipitation, in: Proceedings of the Conference on Cloud Physics, Amer. Meteorol. Soc: Boston, Everett, WA, USA, August 1999, 217-220, 1998.
Ramis, C.: Las observaciones de la atmósfera libre en Mallorca: una breve historia y algunos resultados, Rev. de Ciènca, 17, 4158, 1995 (in Spanish).

Reale, O., Feudale, L., and Turato, B.: Evaporative moisture sources during a sequence of floods in the Mediterranean region, Geophys. Res. Lett., 28(10), 2085-2088, doi:10.1029/ 2000GL012379, 2001.

Ricard, D., Ducrocq, V., and Auger, L.: A climatology of mesoscale environment associated with Mediterranean Heavy Precipitating Events over a Northwestern Mediterranean area, J. Appl. Meteorol. Clim., submitted, 2010.

Rivrain, J.-C.: Les épisodes orageux à précipitations extrêmes sur les régions méditerranéennes de la France, Phénomènes remarquables no. 4, Météo-France, Toulouse, 1997 (in French).

Romero, R., Doswell III, C. A., and Ramis, C.: Mesoscale numerical study of two cases of long-lived quasi-stationary convective systems over eastern Spain, Mon. Weather Rev., 128(11), 3731-3751, 2000.

Scofield, R. A.: Satellite convective categories associated with heavy precipitation, in: Preprints for the 6th Conference on Hydrometeorology, Amer. Meteorol. Soc., Boston, Indianapolis, IN, USA, 29 October 1985, 47-51, 1985.

Simmons, A., Uppala, S., Dee, D., and Kobayashi, S.: ERAInterim: New ECMWF reanalysis products from 1989 onwards, ECMWF, Reading, UK, Newsletter no 110, 25-35, 2007.

Stein, J., Richard, E., Lafore, J.-P., Pinty, J.-P., Asencio, N., and Cosma, S.: High-resolution non-hydrostatic simulations of flash-flood episodes with grid-nesting and ice-phase parameterization, Meteorol. Atmos. Phys., 72, 203-221, doi:10.1007/ s007030050016, 2000.

Stohl, A. and James, P.: A lagrangian analysis of the atmospheric branch of the global water cycle. Part I: method description, validation and demonstration for the August 2002 flooding in Central Europe, J. Hydrometeorol., 5(4), 656-678, 2004.

Tripoli, G. J., Medaglia, C. M., Panegrossi, G., Dietrich, S., Mugnai, A., and Smith, E. A.: Modeling microphysical signatures of extreme events in the Western Mediterranean to provide a basis for diagnosing precipitation from space, in: Measuring Precipitation from Space: EURAINSAT and the Future, Springer, Dordrecht, Netherlands, 535-547, ISBN:14020-5834-9, 2007.

Turato, B., Reale, O., and Siccardi, F.: Water vapor sources of the October 2000 Piedmont flood, J. Hydrometeorol., 5(4), 693-712, 2004.

Uppala, S., Dee, D., Kobayashi, S., Berrisford, P., and Simmons, A.: Towards a climate data assimilation system: status update of ERA-Interim, ECMWF, Reading, UK, Newsletter no 115, 12$18,2008$.

Yan, X., Ducrocq, V., Jaubert, G., Brousseau, P., Poli, P., Champollion, C., Flamant, C., and Boniface, K.: The benefit of GPS zenith delay assimilation to high-resolution quantitative precipitation forecasts: A case-study from COPS IOP 9, Q. J. Roy. Meteor. Soc., 135(644), 1788-1800, doi:10.1002/qj.508, 2009. 